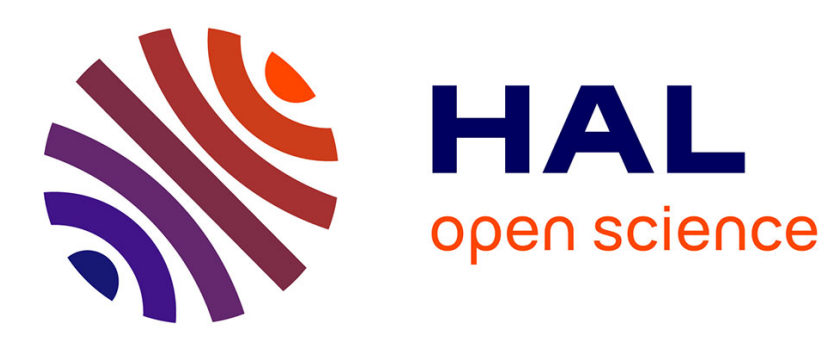

\title{
Retail Pricing Format and Rigidity of Regular Prices
}

Sourav Ray, Avichai Snir, Daniel Levy

\section{To cite this version:}

Sourav Ray, Avichai Snir, Daniel Levy. Retail Pricing Format and Rigidity of Regular Prices. 2021. hal-03448336

\section{HAL Id: hal-03448336 \\ https://hal.science/hal-03448336}

Preprint submitted on 25 Nov 2021

HAL is a multi-disciplinary open access archive for the deposit and dissemination of scientific research documents, whether they are published or not. The documents may come from teaching and research institutions in France or abroad, or from public or private research centers.
L'archive ouverte pluridisciplinaire HAL, est destinée au dépôt et à la diffusion de documents scientifiques de niveau recherche, publiés ou non, émanant des établissements d'enseignement et de recherche français ou étrangers, des laboratoires publics ou privés. 


\title{
Retail Pricing Format and Rigidity of Regular Prices*
}

\author{
Sourav Ray \\ DeGroote School of Business, McMaster University \\ Hamilton, ON L8S-4M4, CANADA \\ sray@mcmaster.ca \\ Avichai Snir \\ Department of Banking \& Finance, Netanya Academic College \\ Netanya 42365, ISRAEL \\ Avichai.Snir@gmail.com \\ Daniel Levy** \\ Department of Economics, Bar-Ilan University \\ Ramat-Gan 52900, ISRAEL \\ Department of Economics, Emory University \\ Atlanta, GA 30322, USA \\ Rimini Center for Economic Analysis, ITALY \\ Research Centre for Economic Analysis, CANADA \\ Daniel.Levy@biu.ac.il
}

November 24, 2021

Key Words: Price Rigidity, Sticky Prices, Regular Prices, Sale Prices, Filtered Prices, Reference Prices, Transaction Prices, Price Cuts, Pricing Format, Every Day Low Price (EDLP), Hi-Lo, Hybrid

JEL Codes: E31

\footnotetext{
* We acknowledge the financial support of the SSHRC (Canada) and the IIMF (McMaster University). All errors are ours.

** Corresponding author: Daniel Levy, Daniel.Levy@biu.ac.il
} 


\title{
Retail Pricing Format and Rigidity of Regular Prices*
}

\begin{abstract}
We study different notions of sale and regular prices, and their variability with store pricing-formats. We use data from three large stores with different pricing-formats (EDLP/Hi-Lo/Hybrid) that are located within 1-km radius. Importantly, the data contain both the actual transaction prices and the actual regular prices as displayed on the store shelves. We combine these data with two "generated" regular price series and study their rigidity. Regular-price rigidity varies with store-formats because different format stores define regular-prices differently. Correspondingly, the meaning of price-cuts varies across store-formats. To interpret the findings, we consider the store pricing format distribution across the US.
\end{abstract}

Key Words: $\quad$ Price Rigidity, Sticky Prices, Regular Prices, Sale Prices, Filtered Prices, Reference Prices, Temporary Price Changes, Transaction Prices, Price Cuts, Pricing Format, Every Day Low Price (EDLP), Hi-Lo, Hybrid

JEL Codes: $\quad$ E31 


\section{Introduction}

Studies of optimal price setting conclude that frequent, but temporary, sale price changes may have different macroeconomic implications than infrequent, but more persistent, regular price changes. ${ }^{1}$ Recent studies of price-setting models therefore distinguish between regular and transaction prices. ${ }^{2}$

An important retail pricing practice not discussed in this literature, however, is that stores that follow different pricing formats have different notions of temporary price changes. Hi-Lo stores charge higher regular prices, but run frequent promotions, temporarily cutting prices below the level of their competitors, which they promote heavily. Every-Day-Low-Price (EDLP) stores, on the other hand, offer stable, everyday low prices. To protect their EDLP image, EDLP stores rarely promote temporary price cuts. Hybrid (HYB) stores take various forms, but in general, they combine some features of the EDLP and Hi-Lo formats, adapting them to their individual settings, which may vary by areas, competitive environments, etc. Ellickson and Misra (2008) show that the three format stores account for equal US market shares: 1/3 EDLP, 1/3 Hi-Lo, and 1/3 HYB.

Our goal is to fill this gap in the literature by studying the effect of pricing formats on price rigidity. We use a unique dataset from three large Canadian food stores. Although the dataset is small (as it was hand-collected), it has three features that are particularly important for the questions we ask. First, both the actual regular and the actual transaction prices are posted on the shelves. Second, the stores are located within a $1 \mathrm{~km}$ radius, serving the same pool of clientele. Third, they differ in their pricing format: one follows Hi-Lo, the second follows EDLP, and the third is a HYB.

We complement the transaction and the regular price series of these stores with two generated price series: filtered prices and reference prices. To assess how the treatment of temporary price changes affects price rigidity, we study the rigidity of the 4 price-series at each store. We also estimate Cox semi-parametric hazard functions, controlling for the effects of covariates, and accounting for the variability in the frequency of price changes across product categories.

We find that the pricing format has a large effect on regular price rigidity. If we follow the stores' own notion of regular prices, then regular prices at the EDLP store are more flexible than at the Hi-Lo or at the HYB stores: the EDLP store changes a regular price on average every 7.0 weeks,

\footnotetext{
${ }^{1}$ The literature uses different terms. In general, "transaction prices” refer to "final prices” or "posted prices," which is the same as the "discounted prices" in case there is a discount or "regular prices" in case there is no discount.

2 Examples include Nakamura (2008), Nakamura and Steinsson (2008, 2013), Eichenbaum et al. (2011), Guimaraes and Sheedy (2011), Midrigan (2011), Klenow and Malin (2011), Campbell and Eden (2014), Beradi et al (2015), Coibion et al. (2015), Kehoe and Midrigan (2015), Anderson et al. (2015, 2017), Eden (2018), Nakamura et al. (2018), DellaVigna and Gentzkow (2019), Levy et al. (2020), Wu (2021), and the studies cited therein.
} 
in contrast to the HYB store-every 18.7 weeks, and the Hi-Lo store-every 24.4 weeks. If we treat filtered prices as regular prices, then regular prices at the HYB and EDLP stores are more flexible than at the Hi-Lo store: the HYB store changes a regular price on average every 21.3 weeks, similar to the EDLP store-every 22.7 weeks, while the Hi-Lo store-every 27.4 weeks. If we treat reference prices as regular prices, then regular prices at the HYB store are more flexible than at the EDLP or at the Hi-Lo stores: the HYB store changes a regular price on average every 24.8 weeks, the EDLP store-every 36.5 weeks, and the Hi-Lo store-every 43.6 weeks. Thus, according to our data, the most flexible regular prices can be 3 times as flexible as the least flexible regular prices, depending on the store format and the definition of a regular price.

We recognize that the empirical studies in this literature usually report their results for filtered (or for reference) price series because they are primarily interested in identifying specific patterns of price changes to match and replicate structural models. For that purpose, knowing how retailers label their regular prices is less consequential.

However, recognizing that different format stores treat temporary price cuts differently might nevertheless matter for three reasons. First, the macroeconomic literature often treats temporary price cuts as pre-planned events, designed to maintain a brand's image and/or market share (Anderson et al. 2017, Warner and Barsky 1995). Our results indicate, however, that different format stores treat temporary price cuts differently, suggesting that they may have different motivation for setting them.

Second, although the stores are located within $1 \mathrm{~km}$ of each other and serve the same clientele, we find that the stores have significantly different regular price rigidity, regardless of the definition of regular prices. Assuming that stores respond to macroeconomic/local shocks only (or mostly) through regular price changes (Anderson et al. 2017), this would imply that the HYB and EDLP stores should have a large advantage over the Hi-Lo store. Yet, the Hi-Lo stores more than survive: 1/3 of the US retail stores follow the Hi-Lo format. Thus, it is likely that at least some stores respond to changes in the economic conditions by changing the frequency/and or the depth of the temporary price cuts they offer (Fox and Syed 2016, Kryvtsov and Vincent 2021).

Third, the geographical variability in the pricing format that was noted above, and the variability in the extent of price rigidity that follows, may be playing a role in the variability of the effects of monetary policy by regions or states as in Angeloni and Ehrmann (2007) and Francis et al. (2012). ${ }^{3}$

\footnotetext{
${ }^{3}$ At the technical level, the geographical variability in the pricing format suggests that removing sale prices from the analysis might be more appropriate in the context of the price data from some regions than others.
} 
The paper is organized as follows. Section 2 discusses the pricing format landscape in the US. Section 3 discusses the determinants of the pricing format. Section 4 describes the data. Section 5 highlight key characteristics of the data. Section 6 discusses temporary price cuts and generated regular prices. Section 7 assesses the rigidity of transaction, regular, filtered, and reference prices. Section 8 describes the robustness tests. Section 9 discusses macroeconomic implications. Section 10 addresses data representativeness and limitations. The paper ends with a summary of key findings, and possible avenues for future research.

\section{Pricing format landscape in the US}

The most common pricing strategies are EDLP and Hi-Lo. EDLP retailers guarantee "every-day low price,” and thus they rarely offer discounts. Hi-Lo (or PROMO) retailers charge higher prices but offer frequent promotions by temporarily cutting prices below the EDLP prices. Hi-Lo retailers also tend to offer better service than EDLP retailers (Hoch et al. 1994, Lal and Rao 1997). Walmart, Costco, and Food Lion, for example, are EDLP retailers, while Target follows a Hi-Lo format. ${ }^{4}$

Hi-Lo retailers appeal to consumers with low opportunity cost of time that make frequent shopping trips in search of best prices. They appeal also to time constrained consumers that look for a quality service (Gauri et al. 2008).

HYB format can take various forms, combining some features of the EDLP and Hi-Lo formats, while adapting the particulars to their own settings, depending on the overall market positioning, local market structure, etc. The specific features of a HYB format can therefore vary by areas, competitive landscape, etc.

Table 1 shows the distribution of food store pricing formats by store type in the US. According to the table, the share of the three pricing formats among large stores is about 33\% EDLP, 30\% Hi-Lo, and 37\% HYB, and among small stores-about 22\% EDLP, 50\% Hi-Lo, and 28\% HYB. ${ }^{5}$

Figure 1 shows the distribution of food store pricing formats across the US. Although all three formats are present in all parts of the US, Ellickson and Misra (2008) find regional variation as follows: EDLP format stores are particularly popular in the South, South East, Southern Central, and the South West; Hi-Lo format stores are particularly popular in the Great Lakes, Southern Central, North East, and West Coast; and HYB format stores are particularly popular in the North West, South West, West Cost, North East and South East.

\footnotetext{
${ }^{4}$ According to Hoch et al. (1994) and Ellickson and Misra (2008), the pricing format space is a continuum along the entire spectrum between the EDLP and Hi-Lo. EDLP stores, for example, might offer occasional promotions. Also, some stores may price at the store or category level (Bolton and Shankar 2003).

${ }^{5}$ For example, among Kroger's stores, the largest US food retailer, 13\% are EDLP, 47\% Hi-Lo, and 40\% HYB (Ellickson and Misra 2008). The data in Table 1 and Figure 1 are based on the 1998 Trade Dimensions survey.
} 


\section{Determinants of the retail pricing format}

The decision which pricing format to adopt is a part of the retailers' overall strategic positioning in the market. This decision is based on the market structure, the socio-demographic profile of the shoppers in the market, the general image the retailer wants to convey, etc. ${ }^{6}$

The constant price policy of EDLP retailers eliminates price uncertainty and thus it appeals to time constrained and large basket-buying consumers (Lal and Rao 1997, Bell and Latin 1998). Indeed, according to Ellickson and Misra (2008), EDLP is the preferred pricing format in markets that serve large, low income households, which is in line with the findings of Bell and Latin (1998) that shoppers with a high sensitivity to the cost of the overall basket, prefer to shop at EDLP format stores, such as Walmart, Food Lion, H.E. Butt, Winn-Dixie, Costco and other similar retailers. HiLo and HYB formats are preferred in markets with high income households, who can afford transportation (e.g., families with cars), who can more easily defer and/or stockpile purchases.

EDLP pricing format is more frequently adopted by large and vertically integrated stores. To serve one-stop shoppers well, a store needs to make large investments to meet the quality and selection expectations of the clientele, which requires holding a wide selection of goods and products, and a well-managed inventory (Lal and Rao 1997, Ellickson and Misra 2008). ${ }^{7}$

During the last two decades, changing consumer habits has prompted many retail chains to operate stores of different formats. For example, Kroger, the largest US retailer by revenue, operates all three format stores. It turns out, however, that the chain's overall strategic positioning also has a significant impact on the individual store's choice of the pricing format (Ellickson and Misra 2008). This suggests scale economies in implementing pricing strategies, which is consistent with the assumption of economics of scope in price setting, as in Lattin and Ortmeyer (1991), Hoch et al. (1994), Lach and Tsiddon (2007), Klenow and Malin (2011), Midrigan (2011), Alvarez and Lippi (2014), and Chakraborty et al. (2015).

Interestingly, it turns out that stores sometimes adopt the pricing format of their competitors. For example, stores located in a market with EDLP stores, might adopt the EDLP format rather than HiLo or HYB. In other words, stores sometimes choose not to use pricing format as a differentiating mechanism. Rather, they use it as a coordinating mechanism. That is, pricing formats sometimes serve as strategic complements, which is characteristic of settings with network effects, suggesting

\footnotetext{
${ }^{6}$ See Messinger and Narasimhan (1997), Lal and Rao (1997), Gauri et al. (2008), and Fassnacht and El Husseini (2013).

${ }^{7}$ The constant price policy may be more efficient from menu cost point of view (Levy et al 1997 and 1998, Dutta et al. 1999). For example, according to the November 1992 issue of Progressive Grocer, "A growing number of operators say they have switched from Hi-Lo pricing [to EDLP]. They cite the inefficiencies of making frequent price changes” (p. 50). Hoch, et al. (1994) also note that EDLP lowers operating costs by lowering in-store labor costs because of less frequent price changes.
} 
that in such situations pricing format matching may serve as a device to increase overall demand and the overall market size (Ellickson and Misra, 2008). ${ }^{8}$

However, although retail food chains might operate stores with different pricing formats, the pricing format is one of the key components of stores' strategic image and strategic positioning in the marketplace. A decision about the pricing format, therefore, has long-term consequences. In light of this, the cost of changing pricing format is likely to be prohibitively expensive. Indeed, there are many examples, including J.C. Penny, Zellers Sears, Montgomery World, etc., that tried to re-position themselves by changing their pricing format, but failed dramatically - many of them went bankrupt. ${ }^{9}$ Consequently, stores do not change pricing formats in response to small and temporary shocks which are frequent, but only as part of long-term strategic decisions.

\section{Data: Transaction prices and regular prices}

Our data come from three large Canadian supermarket stores that belong to three large chains: Loblaw's, Provigo, and Super-C. The stores are located in Montreal's Notre-Dame-de-Grâce neighborhood, a middle-class residential district. ${ }^{10}$ Loblaw's is the largest Canadian retailer, operating 400 stores, with annual revenue of about 50 million Canadian dollars (C\$). ${ }^{11}$ Super-C operates 97 stores, and Provigo 300 stores. $^{12}$

Table 2 reports the stores' size, parking area, annual sales, number of products, and number of employees. Based on sales (equivalent to \$16-\$23 million) and the number of products, these are

\footnotetext{
${ }^{8}$ The effects of shopper demographics and store characteristics could explain how stores could coordinate their pricing formats, but it is unclear why the do it, as it is counter to the standard models. Ellickson and Misra (2008) offer possible explanations. For example, a pricing format consistency across close competitors may signal the shoppers a greater price credibility, because a consistency of prices can increase the shoppers' trust in the retailers (Ortmeyer et al. 1991). Also, pricing format coordination reduces one of the many costs the retailers face (Lal and Rao 1997). As far as we know, however, the literature offers no definite answer to the question. ${ }^{9}$ The Warehouse Group of New Zealand switched from Hi-Lo to EDLP in 2017. In their 2018 annual report, the Group explicitly acknowledges how costly it is to switch pricing strategies. The costs include expected sales and margin declines in the near term (an expected 3-year turnaround), the need to restructure the supply chain, building up the private label lines, and even renegotiating trading cycles with business partners, as part of the move to EDLP. Fast forward to 2020, the effectiveness of the EDLP move is still a "work in progress" with attention now on identifying the right product portfolio and leveraging the better forecasting abilities. These suggest that changing such pricing strategies leaves a long shadow into the future and thus are relatively long term in scope. See: https://www.thewarehousegroup.co.nz/application/files/3815/3775/0583/2018_Annual_Report_EDLP_Case_Study.pdf, https://www.thewarehousegroup.co.nz/download_file/force/1583/174, and https://www.thewarehousegroup.co.nz/download_file/force/2600/174, all accessed November 22, 2021. Iceland, an UK-based frozen goods retailer, had ditched its EDLP strategy in 1997 and went back to Hi-Lo. See: https://www.campaignlive.co.uk/article/icelandfreezes-edlp-policy/63585, accessed November 22, 2021.

${ }_{10}$ The district population is 104,974 , average age $41.2,42.8 \%$ with academic degrees, a median gross household income of $\$ 58,178$, and $8.6 \%$ unemployment rate. As a comparison, the median gross household income in Canada is \$70,336, 54\% with academic degrees, and 6.8\% unemployment rate (Statistics Canada 2016).

${ }^{11}$ Sources: https://mtltimes.ca/Montreal/local-businesses/loblaws-cavendish-store-in-notre-dame-de-grace-becomes-a-provigo/, and https://www.theglobeandmail.com/business/article-loblaw-profit-revenue-gain-as-bigger-baskets-help-offset-slower/, both accessed May 13, 2020.

12 In November 1998, Provigo was purchased by the Loblaw’s Group. Loblaw's and Provigo however, are run independent of each other, each with its own market-positioning, format, and identity. In January 2016, the Loblaw's store in our sample was turned into a Provigo store. We collected the data during July 2003-July 2004, long before that happened. See: https://www.wsj.com/articles/SB909782024300867500, accessed November 18, 2021.
} 
large superstores, comparable to some of the largest US chain stores, such as those studied by Levy et al. (1997) for measuring menu costs.

The three stores differ in their pricing format: Provigo is a Hi-Lo store, Loblaw's is an EDLP store, and Super-C is a HYB store. ${ }^{13}$ Figure 2 shows the stores' locations.

In each store, we hand-collected weekly price data during July 30, 2003-July 23, 2004. Every week, for each good, we recorded either one price or two prices, shown on the shelf price tags. If a good was not on sale, then we recorded the regular price, which was also the transaction prices. If a good was on sale, then the retailer posted the regular price next to the transaction price, and we recorded both. Figure 3 shows actual price tag examples from the three stores.

We thus have two weekly price series for each good at each store: transaction prices and regular prices. Both are classified as such by the store managers. That is, our regular and transaction prices are regular prices and transaction prices as viewed by the store management, and as communicated to the shoppers though shelf price tags. On any week, the two prices of a good differ from each other if the good is on sale on that week. Otherwise, the two prices coincide.

From each store, we have 52 weekly price observations for 89 national brand (NB) goods in 11 product categories. In addition, we have price data for 39 private label $(P L)$ goods (10 at the EDLP store, 10 at the Hi-Lo store, and 19 at the HYB store). ${ }^{14}$ In total, we have 15,912 weekly observations. ${ }^{15}$ In addition to the prices, we recorded the products location: back/middle/front aisle and bottom/eye-level/top shelve. ${ }^{16}$ These serve as controls in the regression equations we estimate.

Although our database is relatively small, it has three unique features. First, we have both the actual regular prices and the actual transaction prices of each product, each week. Thus, we can match the regular prices with the corresponding transaction prices (if they differ), as viewed by the stores' management and the shoppers. Second, the stores in our sample represent three pricing strategies (EDLP, Hi-Lo, and HYB). Third, the stores are located close to each other (Figure 2), catering to consumers from the same geographical area.

Table 3 gives the average regular and transaction prices at each of the stores, along with the results of Wilcoxon rank-sum tests for pairwise comparisons. We find that all pairwise comparisons are statistically significant for both the regular and the transaction prices. The Hi-Lo store has the

\footnotetext{
${ }^{13}$ The pricing format of each store was self-identified by the store managers when we interviewed them. Super-C follows a discount format, a type of HYB format. It offers low daily prices like EDLP stores, but with occasional discounts like Hi-Lo stores, to generate an image of "best deals," in addition to the image of everyday best prices.

${ }^{14} \mathrm{PL}$ goods are specific to each chain/store and therefore they are not comparable across the stores.

15 The total number of observations $n=(89 \times 52 \times 3)+(39 \times 52)=15,912$. Appendix D lists the products included in our sample, and the corresponding regular and transaction prices.

${ }^{16}$ Manufacturers compete for eye-level shelf spaces by paying the supermarkets various slotting and display fees.
} 
highest average regular (transaction) prices, $\mathrm{C} \$ 4.58$ ( $\mathrm{C} \$ 4.47)$, the HYB store has the lowest average regular (transaction prices), C\$3.98 (C \$3.94), and the EDLP has average regular (transaction) price in-between C\$4.12 (C\$4.11).

\section{Sample price series: A general picture and some characteristics}

To illustrate price behavior, we depict in Figure 4 the regular and transaction price series at the three stores for five products: (1) Dishwashing Liquid, (2) Perrier, (3) Frozen Dessert, (4) Eggs, and

(5) Cheerios. A visual examination of the plots leads to the following general observations:

a) Average prices at the Hi-Lo store are higher than at the EDLP and HYB stores.

b) The Hi-Lo store offers frequent and deep temporary price cuts, where its price falls below the EDLP and HYB prices.

c) The price gaps between the EDLP and HYB stores are small. For three products (Dishwashing Liquid, Frozen Dessert, and Cheerios), the average EDLP store prices are below the HYB store prices, and for two products (Perrier and Eggs) it is the other way around.

d) The transaction prices at the Hi-Lo store change more often than at the other stores.

e) The regular prices at the EDLP store change more frequently than at the other stores.

f) The total number of price changes at the EDLP and HYB stores are similar. But there is an important difference between them: at the EDLP store, the vast majority of these price changes are presented as changes in regular prices, whereas at the HYB store, most price changes are classified as sale prices. ${ }^{17}$

g) The EDLP store rarely presents temporary price cuts as sales. In our entire data, we find only 12 price cuts that the EDLP store classifies as "sales." Figure 4 shows one such case - the sale of eggs at the start of the sample period. This is characteristic of EDLP stores pricing: when it defines a price cut as a "sale," it is usually an exceptionally deep price cut.

h) Temporary price cuts that are not sales occur also at the Hi-Lo and HYB stores. For example, in the price of Perrier at the Hi-Lo store, we see price cuts on the $8^{\text {th }}$ and $35^{\text {th }}$ weeks, which the store classifies and presents as a cut in the regular price. Such temporary regular price changes are rare in the Hi-Lo and HYB stores.

i) Sales do not always end with the pre-sale price. Sometimes the post-sale price is lower than the pre-sale price. For example, at the Hi-Lo store, on the $43^{\text {rd }}$ week, there is a sale of Perrier, but when the price returns to the regular price after the sale ends, the new regular price is below the

\footnotetext{
${ }^{17}$ Consequently, there are many temporary price cuts at the EDLP store which visually resemble “sales” (i.e., deep and temporary price cuts), but which the store classifies and presents as changes in regular prices.
} 
previous regular price.

j) Consistent with Anderson et al. (2017), the post-sale price may exceed the pre-sale price as well. For example, the transaction price of Frozen Dessert at the HYB store drops on the $31^{\text {st }}$ week because of a sale, and then it goes back up, but to a higher level than before the sale. We see a similar event in the case of Eggs at the HYB store on the $21^{\text {st }}$ week.

k) Prices sometimes go up for very short periods, consistent with Chahrour (2011) and Fox (2015). For example, the price of Dishwashing Liquid at the EDLP store, on the $47^{\text {th }}$ week, or the price of Frozen Dessert at the EDLP store, on the $33^{\text {rd }}$ week.

To summarize, the Hi-Lo store offers far more temporary price cuts than the other two stores. In addition, at the Hi-Lo and HYB stores, when the transaction prices are temporarily reduced, the regular prices usually remain unchanged. At the EDLP store, in contrast, the temporary price cuts are treated by the store as cuts in regular prices.

Thus, at the Hi-Lo and HYB stores, when a price is temporarily cut, buyers observe the reduced price along with the unchanged regular price, allowing them to assess the gains from buying at the reduced price. This also alerts them that if they do not buy now, they will likely face higher prices next time. Consumers, facing such situations, are likely to buy more than they would normally do, especially if the good is storable (Hendel and Nevo 2013, Fox and Syed 2016, Glandon 2018).

When an EDLP store temporarily reduces the price, however, the consumers likely treat the reduced price as a regular price because that is how the store presents it. In such situations, they have no incentive to buy more than they would normally do, as they do not see any sign that hints at the possibility of higher prices in the weeks ahead.

\section{Temporary price cuts and generated regular prices}

To assess the effect of the store-pricing format on price rigidity/flexibility, we consider the behavior of four price series for each good, at each store. The first two price series are the transaction and regular price series as defined by the store. These are the actual prices we handcollected from the store shelves. The third is a filtered price series which we generated by employing the Nakamura and Steinsson's (2008) sales filter A, assuming, following Chahrour, that sales last 6 weeks or less. The fourth price series is a reference price series which we generate using Chahrour's (2011) algorithm, using a 13-week rolling window. ${ }^{18}$

\footnotetext{
${ }^{18}$ Eichenbaum et al. (2011) define a reference price as the modal price in a quarter, but we have only 52 weeks of data, and thus with their algorithm we would have a maximum of four price changes per good. Klenow and Malin (2011) define a reference price based on the modal price in a 13-observation rolling window. Chahrour (2011) and Kehoe and Midrigan (2015) suggest that such an algorithm might result in the reference price changing either too early or too late and offer procedures for mitigating this problem.
} 
Figure 5 demonstrates the properties of the resulting price series. The figure shows the transaction, regular, filtered and reference prices of a dishwashing liquid at the EDLP, Hi-Lo and HYB stores. ${ }^{19}$ At the EDLP store, there is a small number of V-shaped price cuts that look like sale prices, but the EDLP store views them as regular price changes, and thus the transaction and regular prices at the EDLP store coincide. The filtered prices are smoother because the filter removes all Vshaped price cuts. The reference prices are similar to the filtered prices, with the exception that the Chahrour's (2011) filter also removes the one-week price hike that occurs on the $48^{\text {th }}$ week.

At the Hi-Lo store, regular prices last long periods, with frequent V-shaped price cuts. Consequently, transaction prices are more volatile than regular prices. The filtered series resemble the regular series, demonstrating that the filter performs well with the Hi-Lo store data. The reference price series is a smoothed transaction price series, and thus, in this case, it remains unchanged during the sample period.

The HYB store offers few V-shaped transaction price cuts, and thus its regular prices are smoother than the transaction prices. The filtered prices are similar to regular prices, suggesting that the sales filter performs well also at the HYB store. The only place where it misses a sale is at the end of the sample period, where the price cut is treated by the filter as a regular price change because it "cannot find” a price increase that must follow the price cut.

Figure 5 illustrates well the general pattern found in our data. We summarize the findings on temporary price cuts in Table 4, which shows the number of sale events according to the various price series. Column 1 reports the number of promoted sales, defined as periods when a stores' transaction price was below the store's regular price, thus informing the consumers that a product is on sale. Column 2 reports the number of filtered sale events, defined as periods when the filtered price is above the transaction price. Column 3 reports the number of reference sale events, defined as periods when the reference price is above the transaction price. Columns 4-6 give the results of Pearson $\chi^{2}$-tests for comparing the shares of price changes between each pair of stores.

The results underscore the differences in the way the stores use and treat temporary price cuts. According to all definitions, the Hi-Lo store uses more temporary price cuts than the other stores. It had 507 promoted sale events, 509 price cuts that the Nakamura and Steinsson's (2008) sales filter A defined as filtered sale events, and 502 price cuts that the Chahrour's (2011) algorithm defined as reference sale events. All these numbers are significantly larger than at either of the other stores.

The EDLP store offers 12 promoted sales, significantly less than at either the Hi-Lo store (507

${ }^{19}$ The regular and the transaction prices of this product are also shown in the top row of Figure 4. 
promoted sales) or the HYB store (265 promoted sales). However, the number of temporary price cuts at the EDLP and HYB store are similar. According to the sales filter, there are 265 filtered sale events at the EDLP store and 279 in the HYB store. According to the Chahrour's (2011) algorithm reference prices, there are 267 sale events at the EDLP store and 273 at the HYB store. In both cases, the differences are not statistically significant.

Thus, according to all price series, the Hi-Lo store has significantly more temporary price cuts than any of the other stores. The EDLP and HYB store have a similar number of temporary price cuts, but the HYB store promotes them as sales, while the EDLP store does not. Instead, the EDLP store treats most of these price cuts as regular price changes.

\section{Variation in price rigidity: Price change frequency and price spell duration}

\subsection{Summary statistics}

Given the emphasis in the literature on the different effects that regular and sale prices have on the aggregate price level, it is of interest to study how the stores' different treatment of temporary price cuts affect their price rigidity. In Panel A of Table 5, we present category-level average weekly price change frequencies at each store for the 11 product categories, for each of the four price series (transaction, regular, filtered, and reference). The averages are computed over all goods in each category. Panel B of Table 5 gives the implied average price duration in weeks, calculated as $-[\ln (1-\bar{f})]^{-1}$, where $\bar{f}$ is the average weekly price change frequency (Levy et al. 1997, Nakamura and Steinsson 2008).

The figures in the table indicate a substantial heterogeneity in the average frequency of weekly transaction price changes across categories, consistent with Bils and Klenow (2004) and Nakamura and Steinsson (2008). Except for the EDLP store, which treats temporary price cuts as regular price changes, the price variability is smaller for regular prices than for transaction prices. In all stores, the variance is even smaller for the filtered and for the reference prices.

Despite the heterogeneity we find across categories, however, when we compare across stores, we find a consistent pattern. We therefore compare the overall average frequencies across stores rather than across categories. Table 6 presents the results of Pearson $\chi^{2}$-tests of proportions of price changes for pairwise comparisons.

The Hi-Lo store has the highest frequency of weekly transaction price changes, $23.25 \%$, compared to $13.83 \%$ and $13.76 \%$ at the EDLP and HYB stores, respectively. The differences between the Hi-Lo and the EDLP stores, and between the Hi-Lo and the HYB stores, are significant $\left(\chi^{2}=151.27\right.$ and $\chi^{2}=161.69$, respectively, $p<0.01$ in both cases). There is no statistically 
significant difference between the EDLP and HYB stores $\left(\chi^{2}=0.01, p>0.92\right)$.

If we look at the regular prices as defined by the stores, then the EDLP store has the highest frequency of weekly price changes with $13.38 \%$, compared to $4.02 \%$ and $5.22 \%$ at the Hi-Lo and HYB stores, respectively. All pairwise differences are statistically significant, with the $\chi^{2}$-statistics being 284.01 and 216.06 for comparing the EDLP store with the Hi-Lo and HYB stores, respectively, and 8.68 for comparing the Hi-Lo store with the HYB store ( $p<0.01$ in all cases).

Thus, if we look at the stores' notion of transaction prices, the Hi-Lo store changes the transaction prices every 3.78 weeks, the EDLP store every 6.72 weeks, and the HYB store every 6.76 weeks. If we look at the regular prices, however, the Hi-Lo store has the most rigid regular prices: the regular prices change at the Hi-Lo store, on average, every 24.37 weeks, compared to 6.96 and 18.65 weeks at the EDLP and HYB stores, respectively.

The results are somewhat different for the filtered series. The average frequency of filtered price changes at the EDLP and HYB stores, $4.31 \%$ and $4.58 \%$, respectively, are about the same $\left(\chi^{2}=\right.$ $0.44, p>0.50$ ), and both exceed the corresponding figure at the Hi-Lo store, $3.59 \%$. The $\chi^{2}$ statistics for comparing the Hi-Lo store with the EDLP and HYB stores, are $3.50(p<0.07)$ and $6.58(p<0.02)$, respectively.

Focusing on the reference prices, i.e., "long-lived” prices, the HYB store has the highest frequency of weekly price changes with 3.95\%., exceeding the frequency at the EDLP, 2.70\% $\left(\chi^{2}=13.01, p<0.01\right)$, and the Hi-Lo store, 2.27\% $\left(\chi^{2}=24.86, p<0.01\right)$. The gap between the EDLP and Hi-Lo stores is not significant $\left(\chi^{2}=1.94, p>0.16\right)$.

Thus, if we consider the filtered prices, then the EDLP and HYB stores have more flexible prices than the Hi-Lo store. If we look at the reference prices, then the HYB has the most flexible prices.

\subsection{Econometric estimation}

The results above are suggestive, but they could be affected by heterogeneity across goods, categories, etc. To account for the effects of covariates, while controlling for cross-category heterogeneity in the average frequency of price changes, we estimate a series of Cox semiparametric hazard functions, one regression for each series of price changes:

$$
h(t)=h_{0}(t) \times \exp \left(\beta_{1} E D L P+\beta_{2} H Y B+X \gamma+Z \delta\right)
$$

where $h(t)$ is the hazard of a price change at time $t$, and $h_{0}(t)$ is the baseline hazard when all covariates are equal to 0 . The main covariates are dummies for the EDLP and HYB stores. $X$ are further covariates, which include the price level of the good, defined for each store as the average 
transaction price over the sample period, a dummy for PL product, a dummy for price changes made in January, and a dummy for price changes made in Christmas week. $Z$ include fixed effects for the product location in the stores — for the aisle (back/front/middle) and for the shelf (bottom/top/middle). We allow for recurrent price changes, and we stratify the data by categories to allow the hazard in different categories to be non-proportional.

Table 7 summarizes the estimation results. The values in the table are the proportional changes in the hazard in response to a one-unit change in each covariate. Robust standard errors, clustered at the good-store level, are reported in parentheses.

We find that prices are more likely to change in January, consistent with Nakamura and Steinsson (2008). We also find that with the exception of the regular price series, prices are more likely to change in the Christmas week than at other times. ${ }^{20}$ More importantly, we find that the results of the hazard function estimation corroborate the findings we discuss above. Consider first the hazard function estimate for transaction prices. According to the first column, the hazard that a price will change at the EDLP (HYB) store is 0.66 (0.64) times the hazard at the Hi-Lo store, and the differences are statistically significant $(p<0.01$ in both cases). There are no statistically significant differences between the hazards at the EDLP and HYB stores $\left(\chi^{2}=0.09, p>0.76\right)$.

Next, consider the hazard function estimate for regular prices. Here we find the opposite. The hazard that a regular price will change at the EDLP store is 3.62 times the hazard at the Hi-Lo store $(p<0.01)$. The hazard that a regular price will change at the HYB store is 1.41 times the hazard at the Hi-Lo store $(p<0.01)$. The difference between the EDLP and HYB stores is also significant $\left(\chi^{2}=116.87, p<0.01\right)$.

When we look at the filtered prices, we find that the hazard that a filtered price will change at the EDLP store is 1.16 higher than at the Hi-Lo store. The difference is not statistically significant $(p>$ 0.24). The hazard that a filtered price will change at the HYB store is 1.28 times the hazard at the Hi-Lo store $(p<0.02)$. There is no significant difference between the hazards at the EDLP and HYB stores $\left(\chi^{2}=1.10, p>0.29\right)$.

Finally, considering the reference prices, we find that the hazard that a reference price will change at the EDLP store is 1.20 times the hazard at the Hi-Lo store, but the difference is not statistically significant $(p>0.14)$. The hazard that a reference price will change at the HYB store is 1.70 times the hazard at the Hi-Lo store $(p<0.01)$. The difference between the EDLP and HYB

\footnotetext{
${ }^{20}$ Observing more price changes on Christmas week is consistent with Warner and Barsky (1995) and Levy et al. (2010), who find a higher frequency of price changes on the week prior to Christmas.
} 
stores is significant too $\left(\chi^{2}=10.81, p<0.01\right)$.

In sum, there are significant differences in the price rigidity between the stores, regardless of which price series we consider. If we look at transaction prices, then the Hi-Lo store has the most flexible prices. If we look at regular prices, we find that the Hi-Lo store has the least flexible prices whether as defined by the store, as defined by the Nakamura and Steinsson's sales filter A, or as defined by Chahrour's (2011) algorithm. The EDLP store has the most flexible prices if we look at regular prices as defined by the store. The HYB store has the most flexible prices if we look at reference prices. If we look at the filtered price series, then the EDLP and HYB store have a similar level of price rigidity.

\section{Robustness tests}

We run two robustness tests, which we briefly summarize below. ${ }^{21}$ First, in the paper, we study the price level at each store. We find that the Hi-Lo store has the highest regular and transaction prices, and that the prices at the HYB store are lower than at the EDLP store. Repeating the analyses at the category level, yields similar results. See Appendix A for details.

Second, we assess the extent of price rigidity at the level of product categories. Above, we compare the weekly frequencies of price changes at the store level. We find similar results for category-level data. See Appendix B for more details.

\section{Macroeconomic implications}

These findings are important for several reasons. First, in the macroeconomics literature, temporary price cuts are treated as pre-planned events. Anderson et al. (2017), for example, argue that sales are "demand generating activities" that involve complicated logistics. To simplify the logistics, manufacturers and retailers collaborate to determine the timing and depth of sale events (Warner and Barsky 1995). They therefore view sales as sticky plan events (Reis 2006).

Our results suggest, however, that different stores treat temporary price cuts differently, suggesting that they may have different motivation for setting them. For example, given that the EDLP store does not promote most temporary price cuts, it likely has a lower cost of setting them. Temporary price cuts at an EDLP store, can therefore be more flexible than temporary price changes at a Hi-Lo store, that bases its promotions on sales events. It follows, therefore that price information should be supplemented with information on the stores' pricing format when interpreting price rigidity. Simply using price data while ignoring the store pricing format

\footnotetext{
${ }^{21}$ The Online Supplementary Appendix contains a detailed description of these tests. It also contains a discussion of how our data compares to similar but larger datasets in terms of the distribution of the last digit and the last two digits of the price (Appendix C), and a detailed list of all the products included in our sample (Appendix D).
} 
information, which is the common practice in the literature, can yield misleading statistics about price variability. This is particularly true if one filters the price series before analyzing them. ${ }^{22}$

Second, although the stores are located within $1 \mathrm{~km}$ of each other, we find that the stores have significantly different regular price rigidity, whether we define "regular prices" according to (1) the store's definition, (2) a sales filter, or (3) reference prices. Assuming that stores respond to macroeconomic shocks only (or mostly) through regular price changes (Coibion et al., 2015, Kehoe and Midrigan, 2016, Anderson et al., 2017, DellaVigna and Gentzkow, 2019), this would imply that the HYB and EDLP stores should have an advantage over the Hi-Lo stores. Yet, Hi-Lo stores constitute $1 / 3$ of the retail stores in the US. Thus, it is likely that some of the stores respond to changes in the economic conditions by changing the frequency and/or the depth of the sales they offer. This seems important in light of studies that find that temporary price changes can have macroeconomic implications (Fox and Syed, 2016, Kryvtsov and Vincent, 2021). ${ }^{23}$

However, it is unclear whether temporary price cuts at the EDLP store should have a significant macroeconomic effect. Studies that show that temporary price changes have macroeconomic effects (Fox and Syed 2016, Kryvtsov and Vincent 2021) are partly based on the premise that price cuts are promoted by stores, leading to an increase in the quantities purchased. At the EDLP store, however, most temporary price cuts are not promoted. Consequently, it is not clear whether they have a significant effect on consumers' purchase behavior, limiting their potential effect on the economy.

Third, as noted, there is a substantial geographical variability in the pricing formats adopted by US retailers (Ellickson and Misra 2008). We find that stores that follow different pricing formats have different levels of transaction and regular price rigidity even when they cater to the same pool of clientele. The distribution of stores' pricing formats in each region might, therefore, play a role in the variability in the local effects of monetary policy by regions and/or by states, as in Angeloni and Ehrmann (2007) and Francis et al. (2012). This implies that removing sale prices from the analysis might be more appropriate when studying data from certain regions than from other regions.

\section{Data representativeness and data limitations}

An important caveat that we shall note concerns our dataset's limitations, which is due to the hand-collection process we had to employ to collect it. We only have data from three stores, and for a limited number of products, over a one-year period. Also, we do not have quantity data, and the

\footnotetext{
${ }^{22}$ Hansen and Singh (2009, p. 656) draw a similar conclusion in the context of topics studied by marketing scholars: “...failure to account for retail format effects can substantially bias the understanding of underlying market structure and could lead to incorrect implications in applications."

${ }^{23}$ Our results also suggest that at the level of an individual store, the extent to which temporary price cuts respond to macroeconomic shocks might depend on a store’s pricing format.
} 
dataset itself is somewhat dated (2003-2004). We recognize these shortcomings. An important question, therefore, is whether we can treat the stores we sampled and their price data as a reasonably representative of similar store formats, their price setting practices, etc.

To answer this question, we offer four observations. First, we interviewed the managers of the three stores, where they self-identified and confirmed our information about their store formats, which was consistent with the general public knowledge at the time. They also offered details of how they manage prices in their stores, etc., and these details are consistent with the typical characteristics of their store formats. ${ }^{24}$

Second, we looked at the existing empirical studies that use retail price datasets, focusing on their descriptive statistics. We identified seven studies (all in marketing journals), that use comparable but larger datasets from EDLP and Hi-Lo stores. ${ }^{25}$ The studies use prices of different products, from different locations, and address different questions, yet overall they report that (1) Hi-Lo prices are higher than EDLP prices, (2) the average change in Hi-Lo prices is higher than in EDLP prices, (3) the variance of the change in Hi-Lo prices is higher than in EDLP prices, and (4) Hi-Lo stores offer more deals than EDLP stores. We find similar attributes in our data. The average weekly frequencies of price changes reported by Levy et al. (1997) for HL and EDLP chains, are also consistent with the behavior we document here.

Third, the price behaviors we find at the three stores are typical and consistent with textbook descriptions of similar format stores. For example, the descriptions of price setting and price adjustment practices of EDLP, Hi-Lo, and HYB stores, found in textbooks on retail pricing, are consistent with the pricing behavior found in our data (e.g., Monroe 2002, Nagle and Müller 2017).

Fourth, in Appendix C, we compare the price ending distribution in our data to those found in large scanner datasets (Levy et al. 2011, Anderson et al. 2015, Snir and Levy 2021) and find, consistent with the findings in the literature, that 9- and 99-ending prices are a dominant feature in our data as well.

Thus, the descriptive statistics, and other attributes of the price behavior we report, as well as the pricing practices of the stores in our sample, are all in line with comparable figures and information reported in the literature for larger datasets. We believe, therefore, that our dataset, although small, is still a good representative of the price setting practices of the retailers that follow EDLP, Hi-Lo

\footnotetext{
${ }^{24}$ During the data collection period, one of the coauthors of this paper as well as our RA lived in Montreal, and as part of the general public knowledge, they both knew quite well the pricing formats of the three stores.

${ }^{25}$ These are Hoch et al. (1994), Shankar (1996), Bell and Lattin (1998), Galata et al. (1999), Bolton and Shankar (2003), Voss and Seiders (2003), and Rondan-Cataluña et al (2005). We were unable to find a study that considers a HYB store similar to ours, that also reports the store's regular and transaction price statistics.
} 
and HYB pricing format.

\section{Conclusions and future research}

We use a hand collected dataset to study different notions of sale and regular prices, and their variability with stores' pricing format. The dataset is unique for three key reasons. First, the stores in our sample follow different pricing formats-one is EDLP, the second is Hi-Lo, and the third is HYB. Second, we have both the actual transaction prices and the actual regular prices. Third, the stores are within $1 \mathrm{~km}$ from each other.

We study four price series at each store - the actual transaction prices, the actual regular prices, filtered prices, and reference prices. We find a substantial variability in the extent of price rigidity across the three store formats and across the four price-series.

Irrespective of the measure of regular price we use, we find that the Hi-Lo store has the lowest frequency of regular price changes. If we use the stores' own notion of regular prices, then the HiLo store change the regular price, on average, every 24.4 weeks, compared to 7.0 weeks at the EDLP store, and 18.7 weeks at the HYB store. If we use the filtered series, then we find that the HiLo store changes the regular prices on average every 27.4 weeks, compared to 22.7 weeks at the EDLP store and 21.3 weeks at the HYB store. If we focus on reference prices, we find that the HiLo store changed the regular price on average every 43.6 weeks, compared to 36.5 weeks at the EDLP store, and 24.8 weeks at the HYB store. Thus, in our data, the most flexible regular prices are twice or even 3 times as flexible as the least flexible regular prices, depending on the store format and the definition of regular price.

Our results suggest that the distribution of store pricing format can affect the economy's response to monetary shocks, because both EDLP and HYB stores have a more frequent regular price changes than Hi-Lo stores. Further, if we believe that reference prices are most important, then an economy with a high share of HYB stores is likely to respond faster than economies with more EDLP or Hi-Lo stores.

On the other hand, some studies suggest that temporary price cuts might have large effects on the aggregate effective price level (i.e., the price level that accounts for quantities purchased). ${ }^{26}$ These studies are partly based on the premise that price cuts are promoted by stores, resulting in an increase in the quantities purchased. However, because EDLP stores tend not to promote temporary

\footnotetext{
${ }^{26}$ See Klenow and Willis (2007), Hendel and Nevo (2013), Fox and Syed (2016), Glandon (2018), Chevalier and Kashyap (2019), Kryvtsov and Vincent (2021), and Wu (2021).
} 
price cuts, such price cuts are likely to have only modest effect on sales volumes. ${ }^{27}$ Therefore, temporary price cuts are likely to have only a small effect on the aggregate price level in markets that are dominated by EDLP stores than by Hi-Lo stores.

In addition, if studies do not employ a geographically representative sample of retail stores, then our findings may have implications for the aggregate empirics and for macroeconomic models of price-setting. That is because according to Ellickson and Misra (2008, Table 4, p. 815), there is a regional variation in the distribution of store formats across the US, and thus the effect of sales on the aggregate price level will likely vary across US regions. For example, the effect of sales on inflation will be higher in the Great Lakes region, which has a high share of Hi-Lo stores, than in the South-East region, which has a high share of EDLP stores. This can be important for assessing the variability in the local effects of monetary policy by regions and/or states as in Angeloni and Ehrmann (2007) or Francis et al. (2012), for example.

Future work could consider larger data sets that contain information on stores' pricing formats to explore the robustness of the results we report. Considering our findings, we believe it will be beneficial, when studying the behavior of temporary price cuts and their implications, to focus on the prices from the point of view of both buyers and sellers. Depending on store formats and the corresponding notions of regular and sale prices, store managers and shoppers do not necessarily interpret price cuts as “sales.” Therefore, considering how they interpret price cuts, is important for accurately assessing the effects of micro-level price changes on the aggregate price level.

Another avenue for future research that is worthy of exploring, should be a study of the aggregate implications of our findings. We have argued that the heterogeneity we document in pricing policies can affect the degree of nominal price rigidity. However, just because prices change more/less frequently or by smaller/larger amounts, does not necessarily imply that they are more/less responsive to aggregate shocks. To explore this more methodically, requires developing theoretical framework for assessing how stores with different pricing formats may respond to aggregate shocks. These and similar questions could also be explored empirically with larger datasets that contain information about prices as well as about the stores’ pricing format. We hope that the current manuscript offers a starting point of such an exploration.

\footnotetext{
${ }^{27}$ Note an important difference between temporary price cuts at Hi-Lo vs EDLP stores, as seen from the point of view of consumers. A shopper at a Hi-Lo store knows that the price cut is temporary, and thus s/he has incentive to buy more than usual quantity. At an EDLP store, however, even if the shopper knows that the price is low, s/he does not perceive it as temporary, and therefore s/he has no incentive to buy more than the usual quantity.
} 


\section{References}

Alvarez, F., and F. Lippi (2014), "Price Setting with Menu Cost for Multiproduct Firm,” Econometrica 82(1), 89-135.

Anderson, E., N. Jaimovich, and D. Simester (2015), "Price Stickiness: Empirical Evidence of the Menu Cost Channel,” Review of Economics and Statistics 97(4), 813-826.

Anderson, E., B. Malin, E. Nakamura, D. Simester, and J. Steinsson (2017), “Informational Rigidities and the Stickiness of Temporary Sales," Journal of Monetary Economics 90, 64-83.

Angeloni, I. and M. Ehrmann (2007), "Euro Area Inflation Differentials,” The B.E. Journal of Macroeconomics 7(1).

Barsky, R., M. Bergen, S. Dutta, and D. Levy (2003), “What Can the Price Gap between Branded and Private Label Products Tell Us about Markups?” In Scanner Data and Price Indexes, R. Feenstra and M. Shapiro (Eds.), Chicago, IL: NBER and the University of Chicago Press, pp. 165-225.

Bell, D.R., and J.M. Lattin (1998), "Shopping Behavior and Consumer Preference for Store Price Format: Why 'Large Basket’ Shoppers Prefer EDLP,” Marketing Science 17(1), 66-88.

Beradi, B., E. Gautier and H. Le Bihan (2015), "More Facts about Prices: France Before and During the Great Recession,” Journal of Money, Credit and Banking 47(8), 1465-1502.

Bils, Mark, and Peter J. Klenow (2004), "Some Evidence on the Importance of Sticky Prices," Journal of Political Economy 112, 947-985.

Bolton, R. N., and Shankar, V. (2003),” An Empirically Derived Taxonomy of Retailer Pricing and Promotion Strategies,” Journal of Retailing 79(4), 213-224.

Campbell, J. and B. Eden (2014), “Rigid Prices: Evidence from U.S. Scanner Data,” International Economic Review 55(2), 423-442.

Cavallo, A. (2018), "Scraped Data and Sticky Prices,” Review of Economics and Statistics 100(1), 105-19.

Chahrour, R. (2011), “Sales and Price Spikes in Retail Price Data,” Economics Letters 110, 143146.

Chakraborty, R., P. Dobson, J. Seaton, and M. Waterson (2015), "Pricing in Inflationary Times: The Penny Drops,” Journal of Monetary Economics 76, 71-86.

Chevalier, J., and A. Kashyap (2019), "Best Prices: Price Discrimination and Consumer Substitution,” American Economic Journal: Economic Policy 11(1), 126-159.

Coibion, O., Y. Gorodnichenko, and G.H. Hong (2015), “The Cyclicality of Sales, Regular and Effective Prices: Business cycle and Policy Implications,” American Economic Review 105(3), 993-1029.

DellaVigna, S. and M. Gentzkow (2019), “Uniform Pricing in US Retail Chains,” Quarterly Journal of Economics 134(4), 2011-2084.

Dixon, H., J. Seaton, and M. Waterson (2014), "Price Flexibility in British Supermarkets: Moderation and Recession,” Warwick Working Paper No. 1041.

Dutta, S., M. Bergen, D. Levy, and R. Venable (1999), "Menu Costs, Posted Prices, and Multiproduct Retailers” Journal of Money, Credit and Banking 31, 683-703.

Dutta, S., D. Levy, and M. Bergen (2002), "Price Flexibility in Channels of Distribution: Evidence from Scanner Data,” Journal of Economic Dynamics and Control 26, 1845-1900.

Eden, B. (2018), "Price Dispersion and Demand Uncertainty: Evidence from U.S. Scanner Data," International Economic Review 59(3), 1035-1075.

Eichenbaum, M., N. Jaimovich, and S. Rebelo (2011), "Reference Prices, Costs and Nominal Rigidities,” American Economic Review 101(1), 234-262.

Ellickson, P., and S. Misra (2008), “Supermarket Pricing Strategies,” Marketing Science 27(5), 811-828. 
Fassnacht, M. and S. El Husseini (2013), “EDLP versus Hi-Lo Pricing Strategies in Retailing - a State of the Art Article,” Journal of Business Economics 83, 259-289.

Fox, K.J, and I.A. Syed (2016), "Price Discounts and the Measurement of Inflation,” Journal of Econometrics 191, 398-406.

Francis, N., M. Owyang, and T. Sekhposyan (2012), “The Local Effects of Monetary Policy,” The B.E. Journal of Macroeconomics 12(2), 1-38.

Gagnon, E. and D. López-Salido (2020), “Small Prices Responses to Large Demand Shocks,”

Journal of the European Economic Association 18(2), 792-828.

Galata, G., Randolph, E., Bucklin, R. and Hanssens, D. (1999), “On the Stability of Store Format Choice,” Working Paper, Anderson School, the UCLA.

Gauri, D.K., M. Trivedi, and D. Grewal (2008), "Understanding the Determinants of Retails Strategy: An Empirical Analysis,” Journal of Retailing 84(3), 256-267.

Glandon, P.J. (2018), "Sales and the (Mis)measurement of Price Level Fluctuations,” Journal of Macroeconomics 58, 60-77.

Gorodnichenko, Y. and O. Talavera (2017), "Price Setting in Online Markets: Basic Facts, International Comparisons, and Cross-Border Integration,” American Economic Review 107(1), 249-282.

Gorodnichenko, Y., V. Sheremirov, and O. Talavera (2018), "Price Setting in Online Markets: Does It Click?” Journal of European Economic Association 16(6), 1764-1811.

Guimaraes, B., and K. Sheedy (2011), "Sales and Monetary Policy," American Economic Review 101, 844-876.

Hansen, K., and V. Singh (2009), “Market Structure Across Retail Formats,” Marketing Science 28(4), 656-673.

Hendel, I., and A. Nevo (2013), "Intertemporal Price Discrimination in Storable Goods Markets,” American Economic Review 103(7), 2722-2751.

Hess, J.D. and E. Gerstner (1987), “Loss Leader Pricing and Rain Check Policy,” Marketing Science 6(4), 358-374.

Hoch, S.J., X. Drèze, and M.E. Purk (1994), “EDLP, Hi-Lo, and Margin Arithmetic,” Journal of Marketing 50, 16-27.

Huang, X. (2004), “An Empirical Investigation of Price Rigidity in the Grocery Retail Sector,” MA Thesis, Concordia University Montreal, Quebec, Canada.

Kehoe, P.J. and V. Midrigan (2007), "Sales and the Real Effects of Monetary Policy,” Working Paper No. 652, Federal Reserve Bank of Minneapolis.

Kehoe, P. and V. Midrigan (2015), "Prices Are Sticky After All,” Journal of Monetary Economics 75, 35-53.

Klenow, P. and J. Willis (2007), “Sticky Information and Sticky Prices,” Journal of Monetary

Economics 54, 79-99.

Klenow, P., and B. Malin (2011), "Microeconomic Evidence on Price Setting.” In Friedman, B., Woodford, M. (Eds.), Handbook of Monetary Economics, Volume 3A (North Holland: New York, NY).

Knotek, E. II (2019), “The Roles of Price Points and Menu Costs in Price Rigidity,” Working Paper No. 19-23, Federal Reserve Bank of Cleveland.

Kryvtsov, O. and N. Vincent (2021), “The Cyclicality of Sales and Aggregate Price Flexibility,”

Review of Economic Studies 88, 334-377.

Kurachi, Y., K. Hiraki, and S. Nishioka (2016), "Does a Higher Frequency of Micro-Level Price

Changes Matter for Macro Price Stickiness? Assessing the Impact of Temporary Price Changes,” Working Paper No. 16-E-9, Bank of Japan.

Lach, S., and D. Tsiddon (2007), “Small Price Changes and Menu Costs,” Managerial and 
Decision Economics 28, 649-656.

Lal, R., and R. Rao (1997), "Supermarket Competition: The Case of Everyday Low Pricing," Marketing Science 16, 60-80.

Lattin, J.M. and G. Ortmeyer (1991), “A Theoretical Rationale for Everyday Low Pricing,”

Research Paper No. 1144, Stanford University.

Levy, D., M. Bergen, S. Dutta, and R. Venable (1997), “The Magnitude of Menu Costs: Direct

Evidence from Large US Supermarket Chains,” Quarterly Journal of Economics 112, 791-825.

Levy, Daniel, S. Dutta, M. Bergen, and R. Venable, (1998), "Price Adjustment at Multiproduct

Retailers,” Managerial and Decision Economics 19(2), 81-120.

Levy, D. A. Snir, A. Gotler and H. Chen (2020)," Not All Price Endings Are Created Equal: Price

Points and Asymmetric Price Rigidity,” Journal of Monetary Economics 110 (April), 33-49.

Levy, D. G. Müller, S. Dutta, and M. Bergen (2010) "Holiday Price Rigidity and the Cost of Price

Adjustment," Economica 77(305), 172-198.

Messinger, P., and C. Narasimhan (1997), “A Model of Retail Formats Based on Consumers

Economizing on Shopping Time,” Marketing Science 16(1), 1-23.

Midrigan, V. (2011), "Menu Costs, Multiproduct Firms and Aggregate Fluctuations,"

Econometrica 79(4), 1139-1180.

Monroe, K. (2002), Pricing: Making Profitable Decisions (New York, NY: McGraw Hill).

Müller, et al. (2006), "Private Label Price Rigidity during Holiday Periods," Applied Economics

Letters 13, 57-62.

Nagle, T. and G. Müller (2017), The Strategy and Tactics of Pricing: A Guide to Growing More

Profitably (New York, New York: Routledge).

Nakamura, E. (2008), "Pass-Through in Retail and Wholesale,” American Economic Review:

Papers and Proceedings 98(2), 430-437.

Nakamura, E., and J. Steinsson (2008), "Five Facts about Prices: A Reevaluation of Menu Cost

Models,” Quarterly Journal of Economics 123(4), 1415-1464.

Nakamura, E., and J. Steinsson (2011), "Price Setting in Forward-Looking Customer Markets,"

Journal of Monetary Economics 58(3), 220-233.

Nakamura, E., and J. Steinsson (2013), "Price Rigidity: Microeconomic Evidence and

Macroeconomic Implications,” Annual Review of Economics 5(1), 133-163.

Nakamura, E., J. Steinsson, P. Sun, and D. Villar (2018), “The Elusive Costs of Inflation: Price

Dispersion during the US Great Inflation,” Quarterly Journal of Economics 133(4), 1933-1980.

Narasimhan, C. (1988), “Competitive Promotional Strategies,” Journal of Business 61, 427-449.

Ortmeyer, G., J.A. Quelch, and W. Salmon (1991), "Restoring Credibility to Retail Pricing,” Sloan

Management Review 33(1), 55-66.

Peltzman, S. (2000), “Prices Rise Faster than Fall” Journal of Political Economy 108, 466-502.

Reis, R. (2006), “Inattentive Producers,” Review of Economic Studies 73(3), 793-821.

Rondan-Cataluña, et al. (2005), “Are Hypermarket Prices Different from Discount Store Prices?”

Journal of Product and Brand Management 14(5), 330-337.

Shankar, V. (1996), "Relating Price Sensitivity to Retailer Promotional Variables and Pricing

Policy: An Empirical Analysis,” Journal of Retailing 72(3), 249-272.

Sheremirov, V., (2015), "Price Dispersion and Inflation: New Facts and Theoretical Implications,"

Working Paper No. 15-10, Federal Reserve Bank of Boston.

Snir, A., D. Levy, and H. Chen (2017), "End of 9-Endings, Price Recall, and Price Perceptions,”

Economics Letters 155, 157-163.

Snir, A., and D. Levy (2021), "If You Think 9-Ending Prices Are Low, Think Again,” Journal of

the Association for Consumer Research 6(1), 33-47.

Snir, A., S. Ray, and D. Levy (2021), “Sale Filters,” manuscript in preparation. 
Statistics Canada (2016), Census Profile, 2016 Census, Notre-Dame-de-Grâce-Westmount, Quebec, https://goo.gl/HNoqnk, accessed January 27, 2018.

Sudo, N., K. Ueda, K. Watanabe, and T. Watanabe (2018), "Working Less and Bargain Hunting More: Macroimplications of Sales during Japan’s Lost Decades,” Journal of Money, Credit and Banking 50(2-3), 449-478.

Syed, I. (2015), “Sale Spotter: An Algorithm to Identify Sale Prices in Point-of-Sale Data,” UNSW Business School Research Paper No. 2015 ECON 13.

Voss, G. B., and Seiders, K. (2003), "Exploring the Effect of Retail Sector and Firm Characteristics on Retail Price Promotion Strategy,” Journal of Retailing 79(1), 37-52.

Warner, E., and R. Barsky (1995), “The Timing and Magnitude of Retail Store Markdowns:

Evidence from Weekends and Holidays,” Quarterly Journal of Economics 110(2), 321-352.

Wu, W. (2021), "Sales of Durable Goods and the Real Effects of Monetary Policy," Review of

Economic Dynamics (forthcoming), 13 pages. 
Table 1. Distribution of Store Pricing Formats by Store Type: All US Food Retailers

\begin{tabular}{|l|c|c|c|}
\hline \multirow{2}{*}{ Type of Chain/Store } & \multicolumn{3}{|c|}{ Percentage of } \\
\cline { 2 - 4 } & EDLP Stores (\%) & Hi-Lo Stores (\%) & HYB Stores (\%) \\
\hline (a) Large Chains/Stores & 33 & 30 & 37 \\
\hline Chain & 35 & 29 & 36 \\
\hline Vertically Integrated & 32 & 30 & 38 \\
\hline Large Store Size & 31 & 30 & 39 \\
\hline Many Checkouts & 22 & 50 & 32 \\
\hline (b) Small Chains/Stores & 21 & 47 & 26 \\
\hline Independent & 23 & 52 & 26 \\
\hline Not Vertically Integrated & 22 & 52 & \\
\hline Small Store Size & \multicolumn{3}{|l|}{} \\
\hline Few Checkouts &
\end{tabular}

Notes: The distinction between large vs small stores/chains is based on four criteria: chain/independent, vertically/not-vertically integrated, large/small store, and many/few checkouts. A chain has 11 or more stores, an independent has 10 or less. Vertically integrated firms operate their own distribution centers. Large vs. small store size and many vs. few checkouts are defined by the upper and lower quartiles of the full store level census. The figures are the averages for 17,388 stores in the US, with annual revenues of at least $\$ 2$ million. Source: Ellickson and Misra (2008).

Table 2. General Information on the Stores

\begin{tabular}{|l|c|c|c|}
\hline & EDLP (Loblaw's) & Hi-Lo (Provigo) & HYB (Super-C) \\
\hline Total Floor Area $\left(\mathrm{m}^{2}\right)$ & 7,695 & 2,969 & 7,133 \\
\hline Total Parking Area $\left(\mathrm{m}^{2}\right)$ & 19,204 & 3,021 & 10,700 \\
\hline Annual Sales (in Canadian \$) & 30 million & 24 million & 21 million \\
\hline Total Number of Products & 39,000 & 28,000 & 33,000 \\
\hline Total Number of Employees & 235 & 175 & 180 \\
\hline
\end{tabular}

Table 3. Statistical Significance of the Average Price Differences between the Stores, for Regular and Transaction Prices

\begin{tabular}{|l|c|c|c|c|c|c|}
\hline & $\begin{array}{c}\text { EDLP } \\
\text { (Loblaw’s) }\end{array}$ & $\begin{array}{c}\text { Hi-Lo } \\
\text { (Provigo) }\end{array}$ & $\begin{array}{c}\text { HYB } \\
\text { (Super-C) }\end{array}$ & EDLP vs. Hi-Lo & EDLP vs. HYB & Hi-Lo vs. HYB \\
\hline Regular price & $\mathrm{C} \$ 4.12$ & $\mathrm{C} \$ 4.58$ & $\mathrm{C} \$ 3.98$ & $z=8.66^{* * *}$ & $z=3.16^{* * *}$ & $z=11.42^{* * *}$ \\
\hline Transaction price & $\mathrm{C} \$ 4.11$ & $\mathrm{C} \$ 4.47$ & $\mathrm{C} \$ 3.94$ & $z=6.60^{* * *}$ & $z=3.99^{* * *}$ & $z=10.18^{* * *}$ \\
\hline
\end{tabular}

Notes: The table reports the average regular and transaction prices at each of the store, together with the results of a pairwise comparison of regular and sale prices across the three stores. The EDLP vs. Hi-Lo column reports the results of Wilcoxon rank-sum tests for the equality of the average price at the EDLP store and the average price at the Hi-Lo store. The EDLP vs. HYB column reports the results of Wilcoxon rank-sum tests for the equality of the average price at the EDLP store and the average price at the HYB store. The Hi-Lo vs. HYB column reports the $z$-values of Wilcoxon rank-sum tests for the equality of the average price at the Hi-Lo store and the average price at the EDLP store. ${ }^{* * *} p<0.01$

Table 4. Generated Regular Prices: Promoted Sale Events vs Filtered Sale Events

\begin{tabular}{|l|c|c|c|c|c|c|}
\hline & $\begin{array}{c}\text { EDLP } \\
\text { (Loblaw's) }\end{array}$ & $\begin{array}{c}\text { Hi-Lo } \\
\text { (Provigo) }\end{array}$ & $\begin{array}{c}\text { HYB } \\
\text { (Super-C) }\end{array}$ & EDLP vs. Hi-Lo & EDLP vs. HYB & Hi-Lo vs. HYB \\
\hline Promoted sale events & 12 & 507 & 265 & $\chi^{2}=497.17^{* * *}$ & $\chi^{2}=215.55^{* * *}$ & $\chi^{2}=106.16^{* * *}$ \\
\hline Filtered sale events & 265 & 509 & 279 & $\chi^{2}=83.17^{* * *}$ & $\chi^{2}=0.18$ & $\chi^{2}=95.80^{* * *}$ \\
\hline Reference sale events & 267 & 502 & 273 & $\chi^{2}=77.61^{* * *}$ & $\chi^{2}=0.60$ & $\chi^{2}=96.13^{* * *}$ \\
\hline
\end{tabular}

Notes: The Promoted Sale Events are the number of promoted sales, i.e., the cases where the sale price displayed on the shelf price tag was lower than the regular price posted next to it. The Filtered Sale Events are the number of sale events identified as sales by Nakamura and Steinsson's (2008) sales filter A. The Reference Sale Events are sale events identified as sales by the Chahrour (2011) algorithm. The EDLP vs. Hi-Lo column reports the Pearson $\chi^{2}$-test statistics for the differences in the proportion of sale events between the EDLP store and the Hi-Lo store. The EDLP vs. HYB column reports the Pearson $\chi^{2}$-test statistics for the differences in the proportion of sale events between the EDLP store and the HYB store. The Hi-Lo vs. HYB column reports the Pearson $\chi^{2}$-test statistics for the differences in the proportion of sale events between the Hi-Lo store and the HYB store. ${ }^{* * *} p<0.01$ 
Table 5. Frequency of Price Changes and Implied Price Duration

\section{A. Average Weekly Frequency of Price Changes}

\begin{tabular}{|c|c|c|c|c|c|c|c|c|c|c|c|c|}
\hline \multirow[t]{2}{*}{ Product Category } & \multicolumn{4}{|c|}{ EDLP (Loblaw’s) } & \multicolumn{4}{|c|}{ Hi-Lo (Provigo) } & \multicolumn{4}{|c|}{ HYB (Super-C) } \\
\hline & Transaction & Regular & Filtered & Reference & Transaction & Regular & Filtered & Reference & Transaction & Regular & Filtered & Reference \\
\hline Baby Products \& Foods & $5.77 \%$ & $5.77 \%$ & $1.92 \%$ & $0.77 \%$ & $5.77 \%$ & $0.38 \%$ & $0.38 \%$ & $0.00 \%$ & $6.54 \%$ & $5.38 \%$ & $2.69 \%$ & $3.08 \%$ \\
\hline Beverages & $23.08 \%$ & $22.69 \%$ & $6.92 \%$ & $2.88 \%$ & $35.58 \%$ & $4.23 \%$ & $5.77 \%$ & $1.92 \%$ & $17.83 \%$ & $4.90 \%$ & $3.50 \%$ & $2.97 \%$ \\
\hline Breakfast/Cereals & $14.50 \%$ & $14.20 \%$ & $3.11 \%$ & $2.07 \%$ & $24.26 \%$ & $2.81 \%$ & $2.81 \%$ & $1.48 \%$ & $17.47 \%$ & $4.81 \%$ & $4.65 \%$ & $4.33 \%$ \\
\hline Condiments, Sauces \& Spread & $19.58 \%$ & $19.58 \%$ & $4.37 \%$ & $2.27 \%$ & $29.37 \%$ & $4.72 \%$ & $4.02 \%$ & $2.97 \%$ & $14.96 \%$ & $5.13 \%$ & $4.06 \%$ & $4.49 \%$ \\
\hline Dairy Products & $14.81 \%$ & $14.42 \%$ & $5.96 \%$ & $4.42 \%$ & $15.58 \%$ & $5.38 \%$ & $4.23 \%$ & $3.46 \%$ & $15.38 \%$ & $6.25 \%$ & $5.45 \%$ & $3.85 \%$ \\
\hline Frozen Food & $15.11 \%$ & $14.56 \%$ & $3.85 \%$ & $2.75 \%$ & $21.15 \%$ & $3.57 \%$ & $3.85 \%$ & $1.92 \%$ & $14.74 \%$ & $6.20 \%$ & $5.56 \%$ & $4.06 \%$ \\
\hline Health \& Beauty Aid & $12.31 \%$ & $9.81 \%$ & $5.58 \%$ & $4.23 \%$ & $14.62 \%$ & $7.50 \%$ & $5.96 \%$ & $4.42 \%$ & $10.96 \%$ & $5.00 \%$ & $4.42 \%$ & $4.42 \%$ \\
\hline Households & $9.48 \%$ & $9.48 \%$ & $3.85 \%$ & $2.75 \%$ & $20.33 \%$ & $2.20 \%$ & $2.06 \%$ & $1.24 \%$ & $12.14 \%$ & $5.17 \%$ & $5.29 \%$ & $3.73 \%$ \\
\hline Juices & $15.38 \%$ & $14.90 \%$ & $3.12 \%$ & $1.68 \%$ & $34.38 \%$ & $4.57 \%$ & $4.09 \%$ & $2.16 \%$ & $15.87 \%$ & $6.25 \%$ & $5.29 \%$ & $5.29 \%$ \\
\hline Paper Towel, Tissue \& Pet Supplies & $3.85 \%$ & $3.85 \%$ & $2.75 \%$ & $1.65 \%$ & $18.68 \%$ & $3.02 \%$ & $2.47 \%$ & $3.02 \%$ & $7.69 \%$ & $3.21 \%$ & $3.42 \%$ & $2.56 \%$ \\
\hline Soups/Canned Foods & $11.54 \%$ & $11.54 \%$ & $4.81 \%$ & $3.37 \%$ & $34.62 \%$ & $5.77 \%$ & $1.92 \%$ & $1.44 \%$ & $13.74 \%$ & $5.22 \%$ & $4.67 \%$ & $4.95 \%$ \\
\hline Total & $13.83 \%$ & $13.38 \%$ & $4.31 \%$ & $2.70 \%$ & $23.25 \%$ & $4.02 \%$ & $3.59 \%$ & $2.27 \%$ & $13.76 \%$ & $5.22 \%$ & $4.58 \%$ & $3.95 \%$ \\
\hline \multicolumn{13}{|c|}{ B. Implied Average Price Duration in Weeks } \\
\hline Baby Products \& Foods & 16.83 & 16.83 & 51.58 & 129.37 & 16.83 & 262.66 & 262.66 & NA & 14.78 & 18.08 & 36.67 & 31.96 \\
\hline Beverages & 3.81 & 3.89 & 13.94 & 34.22 & 2.27 & 23.14 & 16.83 & 51.58 & 5.09 & 19.90 & 28.07 & 33.17 \\
\hline Breakfast/Cereals & 6.38 & 6.53 & 31.65 & 47.81 & 3.60 & 35.08 & 35.08 & 67.07 & 5.21 & 20.29 & 21.00 & 22.59 \\
\hline Condiments, Sauces \& Spread & 4.59 & 4.59 & 22.38 & 43.55 & 2.88 & 20.68 & 24.37 & 33.17 & 6.17 & 18.99 & 24.13 & 21.77 \\
\hline Dairy Products & 6.24 & 6.42 & 16.27 & 22.12 & 5.90 & 18.08 & 23.14 & 28.40 & 5.99 & 15.49 & 17.84 & 25.47 \\
\hline Frozen Food & 6.10 & 6.36 & 25.47 & 35.86 & 4.21 & 27.51 & 25.47 & 51.58 & 6.27 & 15.62 & 17.48 & 24.13 \\
\hline Health \& Beauty Aid & 7.61 & 9.69 & 17.42 & 23.14 & 6.33 & 12.83 & 16.27 & 22.12 & 8.61 & 19.50 & 22.12 & 22.12 \\
\hline Households & 10.04 & 10.04 & 25.47 & 35.86 & 4.40 & 44.95 & 48.04 & 80.14 & 7.73 & 18.84 & 18.40 & 26.31 \\
\hline Juices & 5.99 & 6.20 & 31.55 & 59.02 & 2.37 & 21.38 & 23.95 & 45.79 & 5.79 & 15.49 & 18.40 & 18.40 \\
\hline Paper Towel, Tissue \& Pet Supplies & 25.47 & 25.47 & 35.86 & 60.10 & 4.84 & 32.61 & 39.98 & 32.61 & 12.50 & 30.65 & 28.74 & 38.56 \\
\hline Soups/Canned Foods & 8.16 & 8.16 & 20.29 & 29.17 & 2.35 & 16.83 & 51.58 & 68.94 & 6.77 & 18.65 & 20.91 & 19.70 \\
\hline Total & 6.72 & 6.96 & 22.70 & 36.53 & 3.78 & 24.37 & 27.35 & 43.55 & 6.76 & 18.65 & 21.33 & 24.81 \\
\hline
\end{tabular}

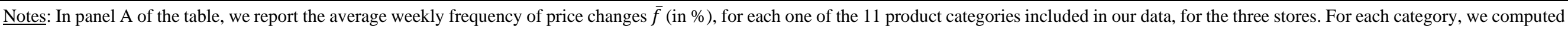

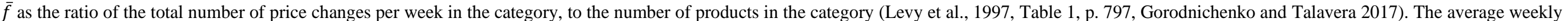

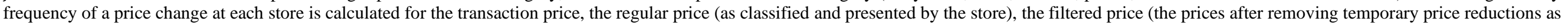

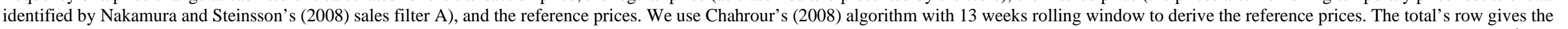

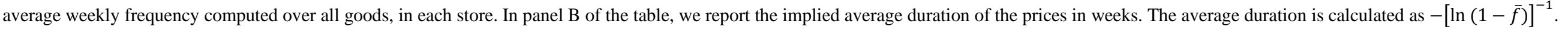


Table 6. Statistical Significance of the Pairwise Differences in the Mean Price Changes Frequency

\begin{tabular}{|l|lll|lll|}
\hline & \multicolumn{3}{|c|}{ EDLP (Loblaw's) } & \multicolumn{3}{c|}{ HYB (Provigo) } \\
\hline \multirow{4}{*}{ Hi-Lo } & Transaction: & $(23.25 \%, 13.83 \%)$ & $\chi^{2}=151.27^{* * *}$ & Transaction: & $(23.25 \%, 13.76 \%)$ & $\chi^{2}=161.69 * * *$ \\
(Provigo) & Regular: & $(4.02 \%, 13.38 \%)$ & $\chi^{2}=284.01^{* * *}$ & Regular: & $(4.02 \%, 5.22 \%)$ & $\chi^{2}=8.68^{* * *}$ \\
& Filtered: & $(3.59 \%, 4.31 \%)$ & $\chi^{2}=3.50^{*}$ & Filtered: & $(3.59 \%, 4.58 \%)$ & $\chi^{2}=6.59^{* *}$ \\
& Reference: & $(2.27 \%, 2.70 \%)$ & $\chi^{2}=1.94$ & Reference: & $(2.27 \%, 3.95 \%)$ & $\chi^{2}=24.86^{* * *}$ \\
\hline \multirow{3}{*}{ EDLP } & & & & Transaction: & $(13.83 \%, 13.76 \%)$ & $\chi^{2}=0.01$ \\
(Loblaw's) & & & & Regular: & $(13.38 \%, 5.22 \%)$ & $\chi^{2}=216.06^{* * *}$ \\
& & & & Filtered: & $(4.31 \%, 4.58 \%)$ & $\chi^{2}=0.44^{* * *}$ \\
& & & Reference: & $(2.70 \%, 3.95 \%)$ & $\chi^{2}=13.01^{* * *}$ \\
\hline
\end{tabular}

Notes: The figures in the parentheses, in the format "(row, column)," are the average weekly price change frequencies at the corresponding pairs of stores. $* p<0.10, * * * p<0.01$

Table 7. The Hazard of a Price Change

\begin{tabular}{|l|c|c|c|c|}
\hline & $\begin{array}{c}\mathbf{( 1 )} \\
\text { Transaction Prices }\end{array}$ & $\begin{array}{c}\mathbf{( 2 )} \\
\text { Regular } \\
\text { Prices }\end{array}$ & $\begin{array}{c}\mathbf{( 3 )} \\
\text { Filtered } \\
\text { Prices }\end{array}$ & $\begin{array}{c}\mathbf{( 4 )} \\
\text { Reference } \\
\text { Prices }\end{array}$ \\
\hline EDLP Store & $0.66^{* * *}$ & $3.62^{* * *}$ & 1.26 & 1.20 \\
& $(0.063)$ & $(0.410)$ & $(0.159)$ & $(0.146)$ \\
\hline HYB Store & $0.64^{* * *}$ & $1.41^{* * *}$ & $1.28^{* * *}$ & $1.70^{* * *}$ \\
& $(0.052)$ & $(0.144)$ & $(0.124)$ & $(0.162)$ \\
\hline Price Level & 0.99 & $1.02^{*}$ & 1.02 & 1.02 \\
& $(0.011)$ & $(0.009)$ & $(0.014)$ & $1.136)$ \\
\hline Private Label & $0.70^{* * *}$ & 0.85 & 0.84 & $(0.140)$ \\
\hline January Dummy & $(0.082)$ & $(0.102)$ & $(0.097)$ & $2.61^{* * *}$ \\
& $1.29^{* *}$ & $1.38^{* *}$ & $2.78^{* * *}$ & $(0.306)$ \\
\hline Christmas Dummy & $(0.129)$ & $(0.176)$ & $(0.366)$ & $2.45^{* * *}$ \\
& $2.20^{* * *}$ & 1.53 & $6.85^{* * *}$ & $(0.802)$ \\
\hline$\chi^{2}$ & $(0.468)$ & $(0.499)$ & $(3.821)$ & $117.7^{* * *}$ \\
$N$ & $93.69^{* * *}$ & $259.7^{* * *}$ & $86.3^{* * *}$ & 782 \\
\hline
\end{tabular}

Notes: The results of estimating hazard function regressions of the hazard of a price change. The hazard functions allow the hazard for different categories to be non-proportional. Column (1) gives the results for transaction price changes. Column (2) gives the results for regular price changes. Column (3) gives the results for filtered price changes, using Nakamura and Steinsson's (2008) sales filter A, to remove temporary price reductions. Column (4) gives the results for reference price changes, using Chahrour's (2011) algorithm to identify the reference prices. The numbers in the table show the hazard ratios. EDLP Store is a dummy for goods offered at the EDLP store. HYB Store is a dummy for goods offered at the HYB store (base group: Hi-Lo store). Price Level is the average transaction prices over the 52week sample period. Private Label is a dummy for private label goods. January Dummy is a dummy for price changes that occur in January. Christmas Dummy is a dummy for price changes that occur on the week of December 25. The regressions also include fixed effects for the product location in the store, for the aisle (back/front/middle) and for the shelf position (bottom/top/middle). Robust standard errors, clustered at the good-store level, are reported in parentheses. ${ }^{*} p<10 \%$. $* * p<5 \%$. ${ }^{* * *} p<1 \%$. 

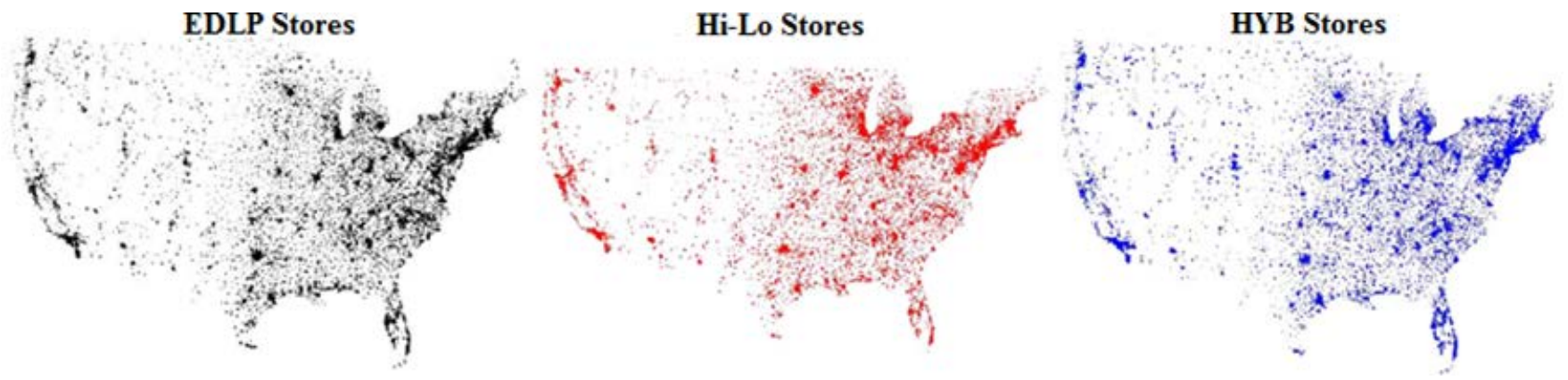

Figure 1. Distribution of Food Stores by Pricing Format across the US (Source: Ellickson and Misra 2008)

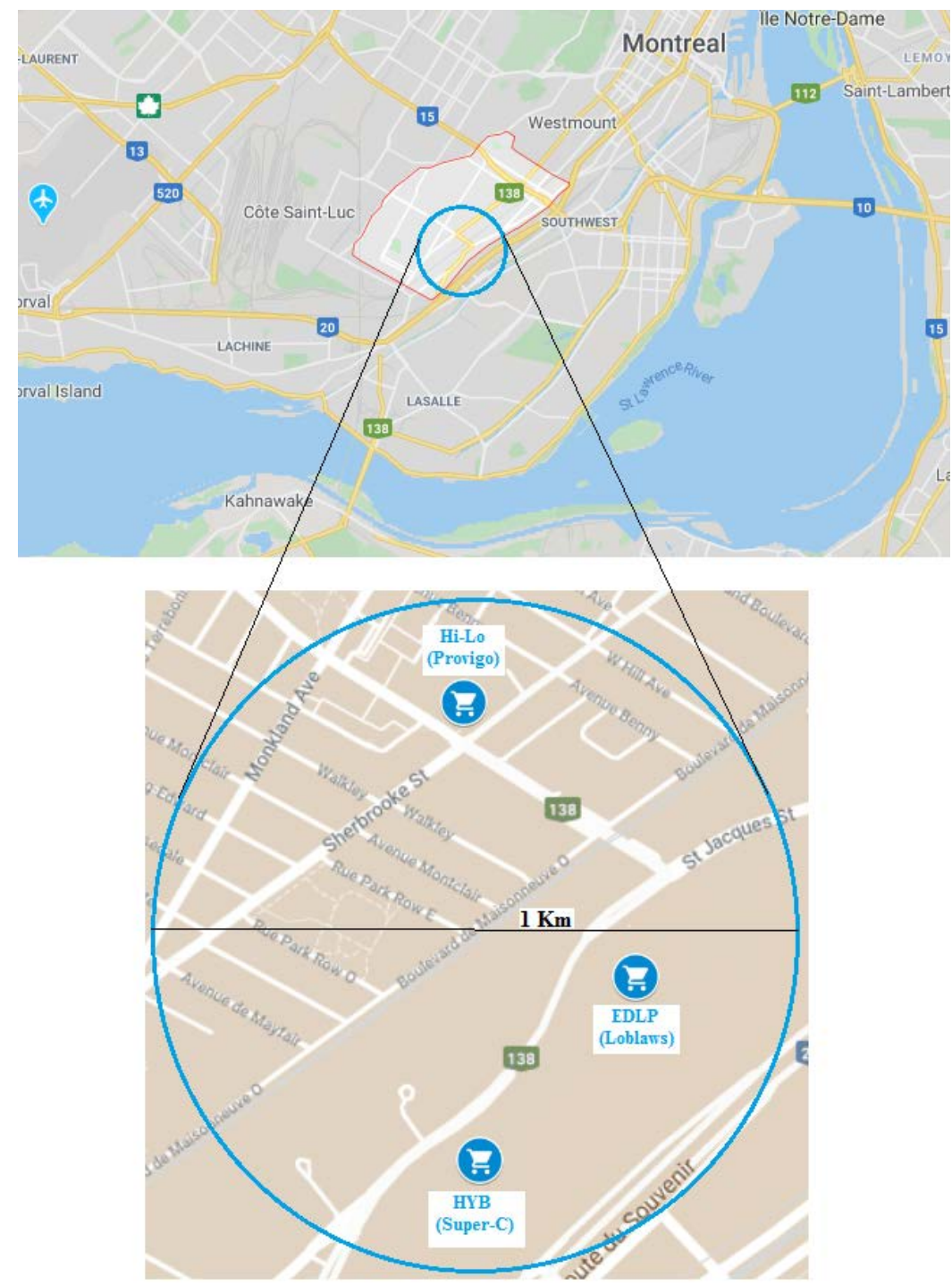

Figure 2. Notre-Dame-de-Grâce District in Montreal, Canada, (the Red Polygon, Top Map), and the Location of the Three Stores in the District (Magnified Blue Circle, Lower Map)

Notes: The exact addresses of the stores are: Provigo (Hi-Lo): 6485 Sherbrooke Street, W., Montreal; Loblaw's (EDLP): 6600 St Jacques Street, Montreal; and Super-C (HYB): 6900 St Jacques Street, Montreal 

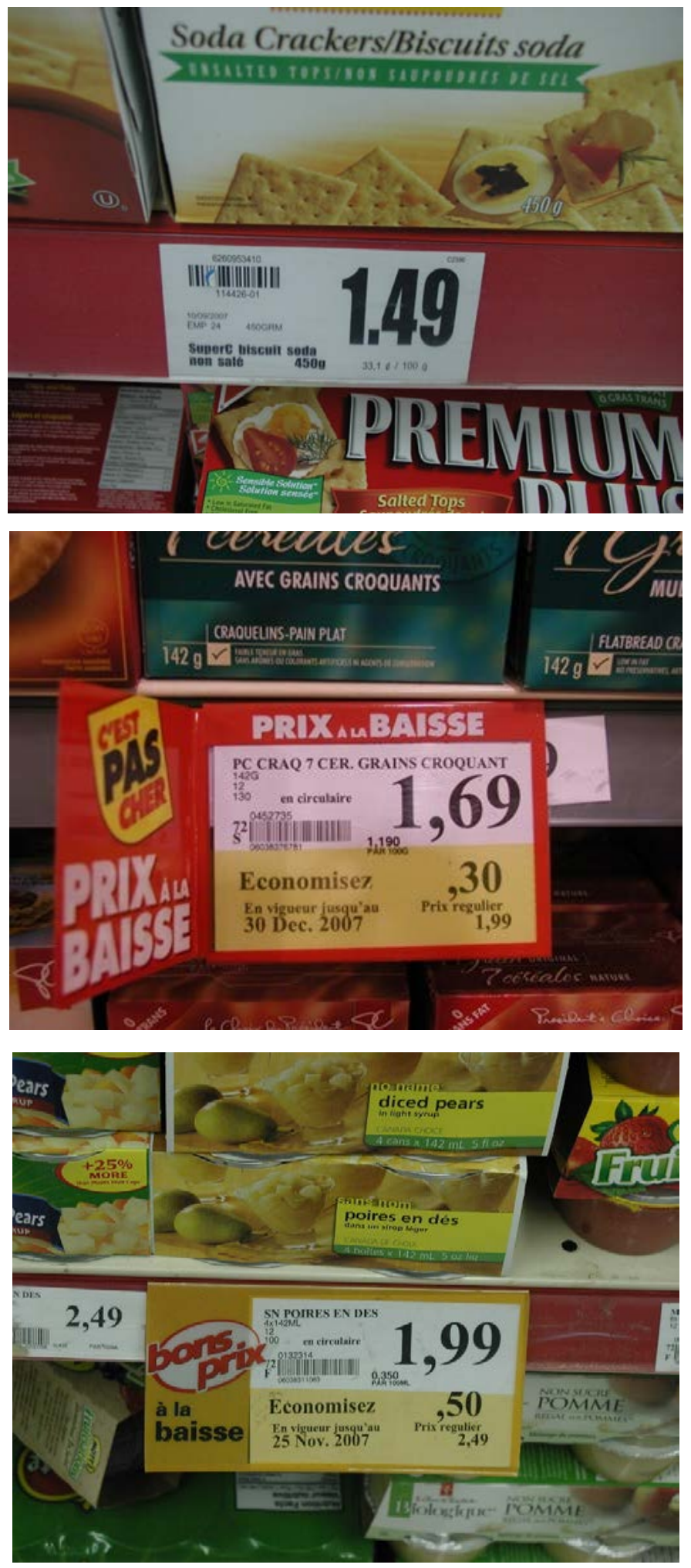

Figure 3. Price Tag Examples with Transaction and Regular Prices

Notes: The top image shows the transaction price (C\$1.49), which is also the regular price, of Biscuit Soda at Super-C (HYB). The middle image shows the transaction price (C\$1.69) and the regular price (C\$1.99) of Grains Croquant at Loblaw's (EDLP). The bottom image shows the transaction price (C\$1.99) and the regular price (C \$2.49) of Poires en Dés at Provigo (Hi-Low). 

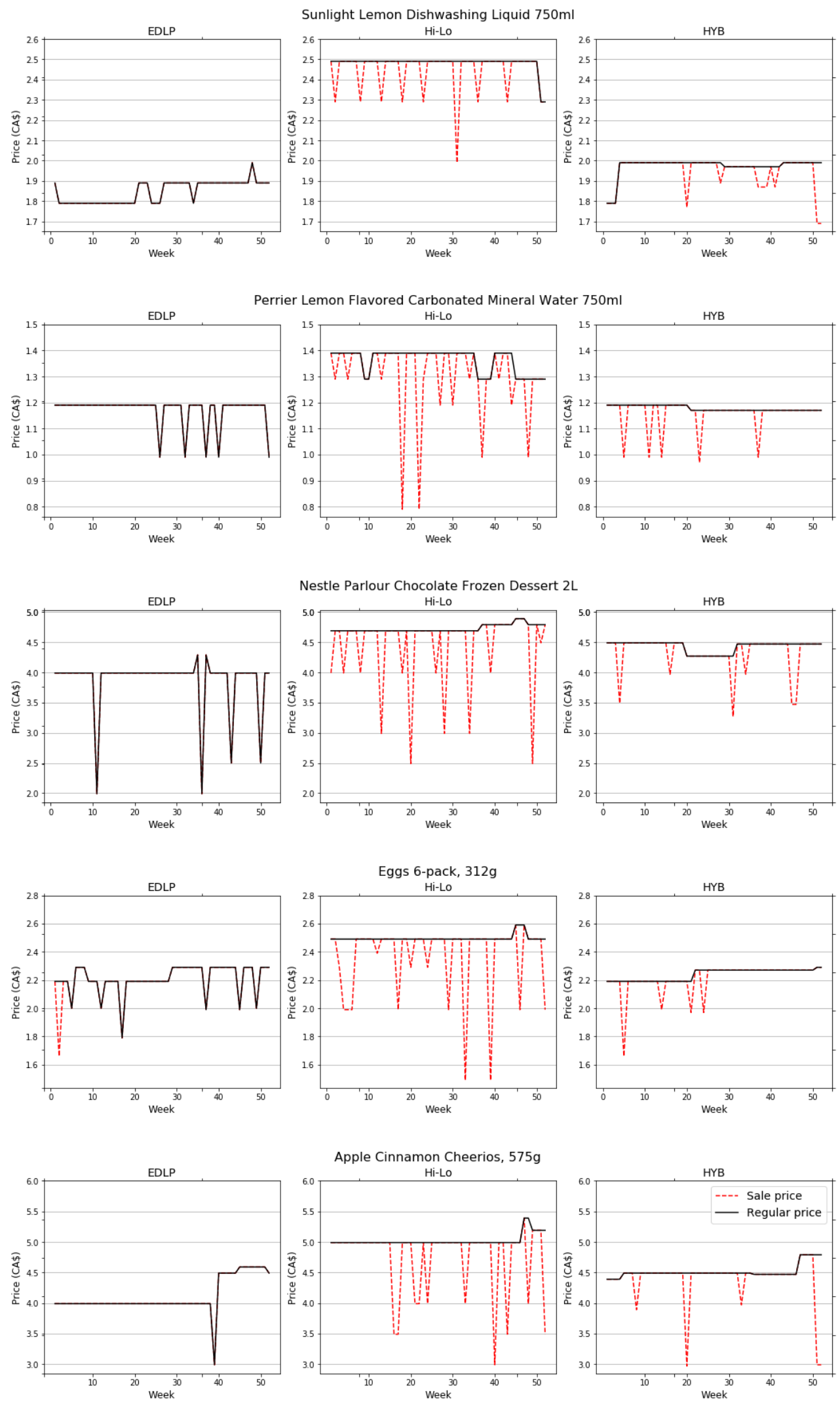

Figure 4. Examples of Weekly Regular Prices (Black Solid Line) and Weekly Transaction Prices (Red Dotted Line) for Five National Brand Goods at the Three Stores (EDLP, Hi-Lo, and HYB), July 30, 2003-July 23, 2004 

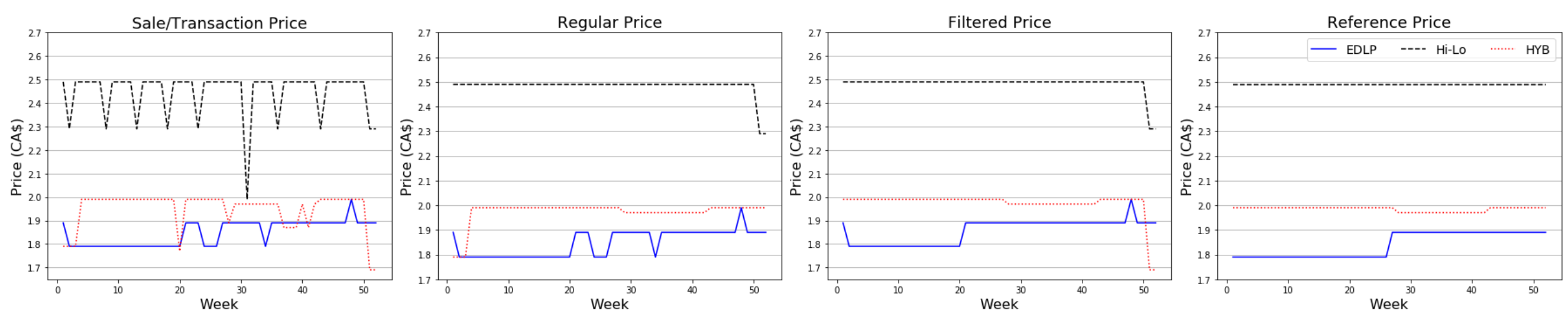

Figure 5. Four Weekly Price Series (Transaction Price, Regular Price, Filtered Price, and Reference Price) of Sunlight Lemon Dishwashing Liquid 750ml. at the Three Stores: EDLP (blue solid line), Hi-Lo (black dashed line), and HYB (red dotted line), July 30, 2003-July 23, 2004 


\title{
Online Supplementary Appendix
}

\section{Retail Pricing Format and Rigidity of Regular Prices}

\author{
Sourav Ray \\ DeGroote School of Business, McMaster University \\ Hamilton, ON L8S-4M4, CANADA \\ sray@mcmaster.ca
}

\author{
Avichai Snir \\ Department of Banking \& Finance, Netanya Academic College \\ Netanya 42365, ISRAEL \\ Avichai.Snir@gmail.com
}

\author{
Daniel Levy* \\ Department of Economics, Bar-Ilan University \\ Ramat-Gan 52900, ISRAEL \\ Department of Economics, Emory University \\ Atlanta, GA 30322, USA \\ and RCEA \\ Daniel.Levy@biu.ac.il
}

November 24, 2021

* Corresponding author: Daniel Levy, Daniel.Levy@biu.ac.il 


\section{Table of Contents}

\section{Page}

Appendix A. Robustness Check: Category Level Prices in the Three Stores

Appendix B. Robustness Check: Comparison of the Weekly Frequency of Price Changes across Stores, at the Category Level

Appendix C. Distribution of the Price Endings: Last Digit and Last Two Digits

Appendix D. Detailed List of All the Products Sampled and the Corresponding Regular and Transaction Prices

References

22 


\section{Appendix A. Robustness Check: Category Level Prices at the Three Stores}

In the paper, we show that when looking at the aggregate, store-level data, the High-Low (Hi-Lo) store has the highest regular and transaction average prices. We also show that the price level at the Hybrid (HYB) store is somewhat lower than at the Every Day Low Price $(E D L P)$ store. Below, we show that the same pattern holds when we focus on prices at the category level as well.

Table A1 reports the average regular and transaction prices in each of the three stores. Panel A reports the average regular prices and panel B reports the average transaction prices.

The results are similar for regular and transaction prices, and therefore we discuss only the regular prices. Comparing the EDLP store with the Hi-Lo store, we find that in all the categories, the average prices at the EDLP store are lower than at the Hi-Lo store. In 9 of the 11 categories the differences are statistically significant. In one additional category, the differences are marginally significant. Thus, the prices at the EDLP store are lower than at the Hi-Lo store not only at the aggregate level. They are lower also when we consider individual categories.

Comparing the EDLP store with the HYB store, we find that in 5 categories, the average prices at the EDLP store are lower than at the HYB store. In 2 categories, the differences are statistically significant. In 6 categories, the average prices at the HYB store are lower than at the EDLP store. In 5 of these categories, the differences are statistically significant. Thus, it seems that in some categories, prices at the EDLP store are below those at the HYB store, in some categories the prices in the two stores are quite similar, and in some categories, prices at the HYB store are lower than at the EDLP store. However, there are more categories in which prices are lower at the HYB store than categories in which the prices are lower at the EDLP store. Overall, therefore, the average price at the HYB store is below the average price at the EDLP store.

Comparing the Hi-Lo store with the HYB store, we find that in all the categories, the average prices at the HYB store are lower than at the Hi-Lo store. In 9 of the 11 categories the differences are statistically significant. Thus, the prices at the HYB store 
are lower than at the Hi-Lo store not only at the aggregate level. They are lower also at the level of individual categories. 
Table A1. Category Level Summary Statistics on Average Prices

\begin{tabular}{|c|c|c|c|c|c|c|}
\hline Product Category & $\begin{array}{c}\text { EDLP } \\
\text { (Loblaw's) }\end{array}$ & $\begin{array}{c}\text { Hi-Lo } \\
\text { (Provigo) }\end{array}$ & $\begin{array}{c}\text { HYB } \\
\text { (Super-C) }\end{array}$ & $\begin{array}{c}\text { EDLP vs Hi-Lo } \\
\text { Wilcoxon }\end{array}$ & $\begin{array}{c}\text { EDLP vs HYB } \\
\text { Wilcoxon }\end{array}$ & $\begin{array}{c}\text { Hi-Lo vs HYB } \\
\text { Wilcoxon }\end{array}$ \\
\hline Baby Products \& Foods & $\begin{array}{c}1.96 \\
(1.129) \\
\end{array}$ & $\begin{array}{c}2.30 \\
(1.099) \\
\end{array}$ & $\begin{array}{c}2.05 \\
(1.103) \\
\end{array}$ & $5.46 * * *$ & $2.90 * * *$ & $5.40 * * *$ \\
\hline Beverages & $\begin{array}{c}6.54 \\
(8.126)\end{array}$ & $\begin{array}{c}7.00 \\
(8.565)\end{array}$ & $\begin{array}{c}5.95 \\
(7.915)\end{array}$ & $4.16^{* * *}$ & $5.23^{* * *}$ & $8.31^{* * *}$ \\
\hline Breakfast/Cereals & $\begin{array}{c}3.94 \\
(1.060)\end{array}$ & $\begin{array}{c}4.37 \\
(0.981)\end{array}$ & $\begin{array}{c}4.10 \\
(1.001)\end{array}$ & $13.56^{* * *}$ & 0.84 & $9.79 * * *$ \\
\hline $\begin{array}{l}\text { Condiments, Sauces \& } \\
\text { Spread }\end{array}$ & $\begin{array}{c}2.53 \\
(0.908)\end{array}$ & $\begin{array}{c}2.91 \\
(1.160)\end{array}$ & $\begin{array}{c}2.63 \\
(1.0125)\end{array}$ & $4.68^{* * *}$ & 0.66 & $3.42 * * *$ \\
\hline Dairy Products & $\begin{array}{c}3.79 \\
(1.657)\end{array}$ & $\begin{array}{c}3.96 \\
(1.743)\end{array}$ & $\begin{array}{c}3.84 \\
(1.562) \\
\end{array}$ & 1.17 & 0.08 & 0.78 \\
\hline Frozen Food & $\begin{array}{c}4.47 \\
(2.279)\end{array}$ & $\begin{array}{c}5.11 \\
(2.621)\end{array}$ & $\begin{array}{c}4.44 \\
(2.298)\end{array}$ & $5.12 * * *$ & 0.72 & $5.01^{* * *}$ \\
\hline Health \& Beauty Aid & $\begin{array}{c}3.28 \\
(1.268)\end{array}$ & $\begin{array}{c}3.61 \\
(1.182)\end{array}$ & $\begin{array}{c}3.50 \\
(1.220)\end{array}$ & $4.05^{* * *}$ & $3.30^{* * *}$ & 1.27 \\
\hline Household & $\begin{array}{c}5.40 \\
(1.995)\end{array}$ & $\begin{array}{c}6.32 \\
(2.246)\end{array}$ & $\begin{array}{c}4.86 \\
(2.015) \\
\end{array}$ & $8.96^{* * *}$ & $4.81^{* * *}$ & $14.00 * * *$ \\
\hline Juices & $\begin{array}{c}2.93 \\
(1.179)\end{array}$ & $\begin{array}{c}3.03 \\
(1.140)\end{array}$ & $\begin{array}{c}2.60 \\
(1.156)\end{array}$ & $1.84 *$ & $4.58^{* * *}$ & $6.09 * * *$ \\
\hline $\begin{array}{l}\text { Paper Towel, Tissue \& } \\
\text { Pet Supplies }\end{array}$ & $\begin{array}{c}6.58 \\
(4.695)\end{array}$ & $\begin{array}{c}7.32 \\
(5.141)\end{array}$ & $\begin{array}{c}5.86 \\
(3.952)\end{array}$ & $4.84^{* * *}$ & $3.71^{* * *}$ & $6.66 * * *$ \\
\hline Soup / Canned Foods & $\begin{array}{c}1.61 \\
(0.665)\end{array}$ & $\begin{array}{c}1.78 \\
(0.685)\end{array}$ & $\begin{array}{c}1.33 \\
(0.609)\end{array}$ & $4.89^{* * *}$ & $8.89 * * *$ & $12.32 * * *$ \\
\hline Overall & $\begin{array}{c}4.12 \\
(3.500)\end{array}$ & $\begin{array}{c}4.58 \\
(3.764)\end{array}$ & $\begin{array}{c}3.98 \\
(3.356)\end{array}$ & $8.66^{* * *}$ & $3.16^{* * *}$ & $11.42 * * *$ \\
\hline
\end{tabular}

\section{B. Transaction Prices}

\begin{tabular}{|c|c|c|c|c|c|c|}
\hline Baby Products \& Foods & $\begin{array}{c}1.96 \\
(1.129)\end{array}$ & $\begin{array}{c}2.29 \\
(1.108)\end{array}$ & $\begin{array}{c}2.04 \\
(1.100)\end{array}$ & $5.22 * * *$ & $2.84 * * *$ & $5.02 * * *$ \\
\hline Beverages & $\begin{array}{c}6.54 \\
(8.127)\end{array}$ & $\begin{array}{c}6.77 \\
(8.480)\end{array}$ & $\begin{array}{c}5.90 \\
(7.875)\end{array}$ & $2.35^{* * *}$ & $5.76 * * *$ & $6.89 * * *$ \\
\hline Breakfast/Cereals & $\begin{array}{c}3.94 \\
(1.060)\end{array}$ & $\begin{array}{c}4.22 \\
(1.019)\end{array}$ & $\begin{array}{c}4.04 \\
(1.015)\end{array}$ & $9.57 * * *$ & 0.75 & $7.48^{* * *}$ \\
\hline $\begin{array}{l}\text { Condiments, Sauces \& } \\
\text { Spread }\end{array}$ & $\begin{array}{c}2.53 \\
(0.908)\end{array}$ & $\begin{array}{c}2.80 \\
(1.127)\end{array}$ & $\begin{array}{c}2.61 \\
(1.013)\end{array}$ & $3.10^{* * *}$ & 0.31 & $2.26 * *$ \\
\hline Dairy Products & $\begin{array}{c}3.78 \\
(1.650) \\
\end{array}$ & $\begin{array}{c}3.91 \\
(1.709) \\
\end{array}$ & $\begin{array}{c}3.79 \\
(1.531) \\
\end{array}$ & 0.65 & 0.39 & 0.66 \\
\hline Frozen Food & $\begin{array}{c}4.47 \\
(2.281)\end{array}$ & $\begin{array}{c}4.96 \\
(2.588)\end{array}$ & $\begin{array}{c}4.39 \\
(2.313)\end{array}$ & $4.11^{* * *}$ & 1.02 & $4.23 * * *$ \\
\hline Health \& Beauty Aid & $\begin{array}{c}3.21 \\
(1.238)\end{array}$ & $\begin{array}{c}3.59 \\
(1.191)\end{array}$ & $\begin{array}{c}3.47 \\
(1.219)\end{array}$ & $4.64^{* * *}$ & $3.37 * * *$ & 1.50 \\
\hline Household & $\begin{array}{c}5.40 \\
(1.995)\end{array}$ & $\begin{array}{c}6.20 \\
(2.247)\end{array}$ & $\begin{array}{c}4.80 \\
(1.990)\end{array}$ & $7.90^{* * *}$ & $5.73 * * *$ & $13.51^{* * *}$ \\
\hline Juices & $\begin{array}{c}2.93 \\
(1.179)\end{array}$ & $\begin{array}{c}2.93 \\
(1.153)\end{array}$ & $\begin{array}{c}2.56 \\
(1.138)\end{array}$ & 0.10 & $5.18 * * *$ & $5.02 * * *$ \\
\hline $\begin{array}{l}\text { Paper Towel, Tissue \& } \\
\text { Pet Supplies }\end{array}$ & $\begin{array}{c}6.58 \\
(4.695)\end{array}$ & $\begin{array}{c}7.27 \\
(5.134)\end{array}$ & $\begin{array}{c}5.85 \\
(3.947)\end{array}$ & $4.45^{* * *}$ & $3.84 * * *$ & $6.49 * * *$ \\
\hline Soup / Canned Foods & $\begin{array}{c}1.61 \\
(0.665)\end{array}$ & $\begin{array}{c}1.71 \\
(0.706)\end{array}$ & $\begin{array}{c}1.31 \\
(0.608)\end{array}$ & $2.88^{* * *}$ & $9.49 * * *$ & $10.57^{* * *}$ \\
\hline
\end{tabular}




\begin{tabular}{|l|c|c|c|c|c|c|}
\hline Overall & $\begin{array}{c}4.11 \\
(3.501)\end{array}$ & $\begin{array}{c}4.47 \\
(3.728)\end{array}$ & $\begin{array}{c}3.94 \\
(3.340)\end{array}$ & $6.60 * * *$ & $3.99 * * *$ & $10.18 * * *$ \\
\hline
\end{tabular}

Notes: The table reports the category-level average prices. The prices are in Canadian Dollars (C\$). The EDLP column gives the average prices at the EDLP store. The Hi-Lo column gives the average prices at the Hi-Lo store. The HYB column gives the average prices at the HYB store. The "EDLP vs Hi-Lo" column gives the values of Wilcoxon rank sum z-test statistics for comparing the EDLP and Hi-Lo store prices. The "EDLP vs HYB" column gives the values of Wilcoxon rank sum $z$-test statistics for comparing the EDLP and HYB store prices. The "Hi-Lo vs HYB" column gives the values of Wilcoxon rank sum $z$-test statistics for comparing the Hi-Lo and HYB stores. * $p<0.10$, $* * p<0.05, * * * p<0.01$ 


\section{Appendix B. Robustness Check: Comparison of the Weekly Frequency of Price Changes across Stores, at the Category Level}

In the paper, we compare the weekly frequencies of price changes at the store level. In this appendix, we show that the results remain unchanged if we conduct the comparisons at the category level. ${ }^{1}$

In Table B1, we report Pearson $\chi^{2}$-test statistics of comparing the frequencies of price changes at the EDLP and Hi-Lo stores. Column 1 reports the results of comparing the frequencies of the transaction price changes, Column 2 reports the results of comparing the frequencies of the regular price changes (as defined and classified by the store), Column 3 reports the results of comparing the frequencies of the filtered price changes, and Column 4 reports the results of comparing the frequencies of the reference price changes. $^{2}$

In each cell, the name of the store indicates the name of the store that has the higher frequency of price changes. In the transaction prices' column, we find that in 10 categories, the Hi-Lo store has a higher frequency of price changes than the EDLP store. In 8 of these 10 categories, the differences are statistically significant.

When we consider the regular prices, we find that in all 11 categories, the frequency of price changes is higher at the EDLP store. In 9 of the 11 categories, the differences are statistically significant.

When we consider filtered prices, we find that the frequency of price changes is higher at the EDLP store in 9 of the 11 categories, but only in one category is the difference statistically significant, and in one additional category it is marginally significant.

When we consider reference prices, we find that the frequency of price changes is higher at the EDLP store than at the Hi-Lo store in 7 of the 11 categories. Only one of the differences is statistically significant.

\footnotetext{
${ }^{1}$ The weekly frequency of price changes is given by the ratio of the total number of price changes per week in the category, to the number of products in the category (Levy et al., 1997, Table 1, p. 797, Gorodnichenko and Talavera 2017).

${ }^{2}$ We obtain the filtered series by using the Nakamura and Steinsson's (2008) sales filter A to remove temporary price reductions from the series of transaction prices. We apply Chahrour's (2011) sales filter to the series of transaction prices to obtain the reference prices.
} 
Thus, when we look at the category level, we find the same pattern as at the overall store level, as discussed in the paper. If we focus on transaction prices, the Hi-Lo store has higher frequency of price changes. When we focus on regular prices, in all categories the EDLP store has higher frequency of price changes. When we focus on filtered prices, the EDLP store has the higher frequency of price changes in 8 out of 11 categories, with one of the differences being statistically significant and another one being marginally significant. When we look at the reference prices, only one of the category level differences are statistically significant.

In Table B2, we report the Pearson $\chi^{2}$-test statistics for comparing the frequencies of price changes at the EDLP and HYB stores. In each cell, we note the name of the store that has the higher frequency of price changes.

In the transaction prices' column, we find that in 4 of the 11 categories, the EDLP store has a higher frequency of price changes than the HYB store. One of the differences is significant statistically and one is marginally significant. In 7 categories, the HYB store has a higher frequency of price changes, where in one case the difference is statistically significant, and in another, the difference is marginally significant.

When we consider regular prices, we find that in all categories, the frequency of price changes is higher at the EDLP store. In 9 of the categories, the differences are statistically significant.

In the filtered prices' column, the frequency of price changes is higher at the EDLP store in 4 categories. None of these differences is statistically significant. At the HYB store, the frequency of price changes is higher in 7 categories. One of the differences is statistically significant.

When we look at the column of reference prices, we find that the frequency of price changes is higher at the HYB store than at the EDLP store in 10 categories. Three of the differences are statistically significant, and one additional difference is marginally significant.

Thus, our findings at the category level, are similar to our findings at the store level. When we look at the transaction and filtered prices, in some categories the EDLP store has higher frequency of price changes, in some the HYB store, but the differences are, at 
most, marginally significant. When we look at the regular prices, in all categories the EDLP store has the higher frequency of price changes. When we look at the reference prices, in 10 of the 11 categories, the frequency of price changes is higher at the HYB store than at the EDLP store.

In Table B3, we report the $\chi^{2}$-test statistics of comparing the average prices at the Hi-Lo and HYB stores. In each cell, the name of the store indicates the name of the store that has the higher frequency of price changes.

In the transaction prices' column, we find that in 10 of the 11 categories, the Hi-Lo store has a higher frequency of price changes than the HYB store. In 8 categories, the differences are statistically significant, and in one additional category it is marginally significant.

When we study the regular prices, we find that in 10 of the 11 categories, the frequency of price changes is higher at the HYB store. In two of the categories, the differences are statistically significant, and in two additional categories, the differences are marginally significant.

In the filtered prices' column, the frequency of price changes is higher at the Hi-Lo store in 2 categories. One of the differences is statistically significant. The frequency of price changes is higher at the HYB store in 9 categories. In 2 categories, the differences are statistically significant and in 2 additional categories, the differences are marginally significant.

When we look at the column of reference prices, we find that the frequency of price changes is higher at the HYB store than at the Hi-Lo store in 10 categories. In 5 categories, the differences are statistically significant, and in one additional category the difference is marginally significant.

Thus, when we look at the category level, we find the same pattern as when we look at the store level. When we consider transaction prices, in 10 of 11 categories the Hi-Lo store has higher frequency of price changes. When we look at the regular prices, in 10 of the 11 categories, the HYB store has higher frequency of price changes. When we look at the filtered prices, the HYB store has higher frequency of price changes in 9 categories. 
When we look at the reference prices, the HYB store has higher frequency of price changes in 10 categories. 
Table B1. Comparing the Frequency of Price Changes at the EDLP and the Hi-Lo Stores

\begin{tabular}{|c|c|c|c|c|}
\hline $\begin{array}{l}\text { Product } \\
\text { Category }\end{array}$ & $\begin{array}{c}\text { Transaction } \\
\text { Prices }\end{array}$ & $\begin{array}{c}\text { Regular } \\
\text { Prices }\end{array}$ & $\begin{array}{c}\text { Filtered } \\
\text { Prices }\end{array}$ & $\begin{array}{c}\text { Reference } \\
\text { Prices }\end{array}$ \\
\hline Baby Products \& Foods & 0.00 & EDLP $12.64 * * *$ & EDLP 2.70 & EDLP 2.01 \\
\hline Beverage & Hi-Lo $19.60^{* * *}$ & EDLP 76.07*** & EDLP 0.58 & EDLP 1.02 \\
\hline Breakfast/Cereals & Hi-Lo 20.62*** & EDLP 56.35*** & EDLP 0.10 & EDLP 0.68 \\
\hline Condiments, Sauces \& Spread & Hi-Lo $14.83^{* * *}$ & EDLP 59.17*** & EDLP 0.09 & Hi-Lo 0.55 \\
\hline Dairy Products & Hi-Lo 0.12 & EDLP 23.80*** & EDLP 1.61* & EDLP 0.63 \\
\hline Frozen Food & Hi-Lo $4.48^{* *}$ & EDLP 26.66*** & 0.00 & EDLP 0.54 \\
\hline Health \& Beauty Aid & Hi-Lo 1.19 & EDLP 1.75 & Hi-Lo 0.07 & Hi-Lo 0.02 \\
\hline Households & Hi-Lo 33.80*** & EDLP 35.10*** & EDLP 4.05** & EDLP 4.26** \\
\hline Juices & Hi-Lo 39.88*** & EDLP 25.29*** & EDLP 0.55 & Hi-Lo 0.25 \\
\hline Paper Towel, Tissue \& Pet Supplies & Hi-Lo $40.14^{* * *}$ & EDLP 0.37 & EDLP 0.05 & Hi-Lo 1.51 \\
\hline Soups/Canned Foods & Hi-Lo 31.20*** & EDLP 4.38** & EDLP 2.66 & EDLP 1.64 \\
\hline Total & Hi-Lo $151.26^{* * *}$ & EDLP $284.01^{* * *}$ & EDLP 3.50* & EDLP 1.94 \\
\hline
\end{tabular}

Notes: The table gives the $\chi^{2}$-test statistics for comparing the average frequencies of weekly price changes in the EDLP and Hi-Lo stores. The transaction price column gives the $\chi^{2}$-test statistics for comparing the average frequency of weekly transaction price changes. The regular price column gives the $\chi^{2}$-test statistics for comparing the average frequency of weekly regular price changes. The filtered price column gives the $\chi^{2}$-test statistics for comparing the average frequency of weekly filtered price changes. The reference price column gives the $\chi^{2}$-test statistics for comparing the average frequency of weekly reference price changes. The name of the store indicates that the average frequency of price changes at that store is higher than the average frequency at the other store. $* p<10 \%$, ** $p<5 \%$, *** $p<1 \%$ 
Table B2. Comparing the Frequency of Price Changes at the EDLP and the HYB Stores

\begin{tabular}{|l|l|l|l|l|}
\hline $\begin{array}{l}\text { Product } \\
\text { Category }\end{array}$ & $\begin{array}{c}\text { Transaction } \\
\text { Prices }\end{array}$ & \multicolumn{1}{|c|}{$\begin{array}{c}\text { Regular } \\
\text { Prices }\end{array}$} & \multicolumn{1}{|c|}{$\begin{array}{c}\text { Filtered } \\
\text { Prices }\end{array}$} & \multicolumn{1}{|c|}{$\begin{array}{c}\text { Reference } \\
\text { Prices }\end{array}$} \\
\hline Baby Products \& Foods & HYB 0.13 & EDLP 0.04 & EDLP 0.34 & HYB 3.67* \\
\hline Beverage & EDLP 4.63** & EDLP 74.49*** & HYB 6.57** & HYB 0.01 \\
\hline Breakfast/Cereals & HYB 2.14 & EDLP 32.71*** & HYB 2.08 & HYB 5.41** \\
\hline Condiments, Sauces \& Spread & EDLP 3.81* & EDLP 47.30*** & EDLP 0.06 & HYB 3.99** \\
\hline Dairy Products & HYB 0.07 & EDLP 21.12*** & EDLP 0.14 & EDLP 0.24 \\
\hline Frozen Food & EDLP 0.02 & EDLP 16.12*** & HYB 1.31 & HYB 1.05 \\
\hline Health \& Beauty Aid & EDLP 0.46 & EDLP 8.77*** & EDLP 0.73 & HYB 0.02 \\
\hline Households & HYB 2.83* & EDLP 10.82*** & HYB 1.83 & HYB 1.18 \\
\hline Juices & HYB 0.04 & EDLP 16.47*** & HYB 2.42 & HYB 8.04*** \\
\hline Paper Towel, Tissue \& Pet Supplies & HYB 5.36** & EDLP 0.25 & HYB 0.31 & HYB 0.81 \\
\hline Soups/Canned Foods & HYB 0.57 & EDLP 7.60*** & HYB 0.01 & HYB 0.79 \\
\hline Total & EDLP 0.01 & EDLP 216.06*** & HYB 0.44 & HYB 13.01*** \\
\hline
\end{tabular}

Notes: The table gives the $\chi^{2}$-test statistics for comparing the average frequencies of weekly price changes in the EDLP and HYB stores. The transaction price column gives the $\chi^{2}$-test statistics for comparing the average frequency of weekly transaction price changes. The regular price column gives the $\chi^{2}$-test statistics for comparing the average frequency of weekly regular price changes. The filtered price column gives the $\chi^{2}$-test statistics for comparing the average frequency of weekly filtered price changes. The reference price column gives the $\chi^{2}$-test statistics for comparing the average frequency of weekly reference price changes. The name of the store indicates that the average frequency of price changes at that store is higher than the average frequency at the other store. ${ }^{*} p<10 \%,{ }^{* *} p<5 \%, * * * p<1 \%$ 
Table B3. Comparing the Frequency of Price Changes at the Hi-Lo and the HYB Stores

\begin{tabular}{|l|l|l|l|l|}
\hline $\begin{array}{l}\text { Product } \\
\text { Category }\end{array}$ & \multicolumn{1}{|c|}{$\begin{array}{c}\text { Transaction } \\
\text { Prices }\end{array}$} & \multicolumn{1}{|c|}{$\begin{array}{c}\text { Regular } \\
\text { Prices }\end{array}$} & \multicolumn{1}{|c|}{$\begin{array}{c}\text { Filtered } \\
\text { Prices }\end{array}$} & \multicolumn{1}{|c|}{$\begin{array}{c}\text { Prefence } \\
\text { Prices }\end{array}$} \\
\hline Baby Products \& Foods & HYB 0.13 & HYB 11.60*** & HYB 4.57** & HYB 8.12*** \\
\hline Beverage & Hi-Lo 44.27*** & HYB 0.28 & Hi-Lo 3.22* & HYB 1.24 \\
\hline Breakfast/Cereals & Hi-Lo 9.02*** & HYB 3.57* & HYB 3.08* & HYB 9.52*** \\
\hline Condiments, Sauces \& Spread & Hi-Lo 30.30*** & HYB 0.09 & HYB 0.00 & HYB 1.68 \\
\hline Dairy Products & Hi-Lo 0.01 & HYB 0.39 & HYB 0.90 & HYB 0.12 \\
\hline Frozen Food & Hi-Lo 5.81** & HYB 2.94* & HYB 1.31 & HYB 3.09* \\
\hline Health \& Beauty Aid & Hi-Lo 3.11* & Hi-Lo 2.77* & Hi-Lo 1.25 & HYB 0.00 \\
\hline Households & Hi-Lo 19.42*** & HYB 9.41*** & HYB 11.12*** & HYB 9.63*** \\
\hline Juices & Hi-Lo 37.89*** & HYB 1.15 & HYB 0.67 & HYB 5.66** \\
\hline Paper Towel, Tissue \& Pet Supplies & Hi-Lo 22.61*** & HYB 0.02 & HYB 0.63 & Hi-Lo 0.16 \\
\hline Soups/Canned Foods & Hi-Lo 34.39*** & Hi-Lo 0.08 & HYB 2.82* & HYB 4.59** \\
\hline Total & Hi-Lo 161.69*** & HYB 8.68*** & HYB 6.59** & HYB 24.86*** \\
\hline
\end{tabular}

Notes: The table gives the $\chi^{2}$-test statistics for comparing the average frequencies of weekly price changes in the Hi-Lo and HYB stores. The transaction price column gives the $\chi^{2}$-test statistics for comparing the average frequency of weekly transaction price changes. The regular price column gives the $\chi^{2}$-test statistics for comparing the average frequency of weekly regular price changes. The filtered price column gives the $\chi^{2}$-test statistics for comparing the average frequency of weekly filtered price changes. The reference price column gives the $\chi^{2}$-test statistics for comparing the average frequency of weekly reference price changes. Positive values indicate that the average frequency of price changes at the HYB store is higher than the average frequency at the Hi-Lo store. ${ }^{*} p<10 \%,{ }^{* *} p<5 \%$, *** $p<1 \%$ 


\section{Appendix C. Distribution of the Price Endings: Last Digit and Last Two Digits}

In Figure C1, we present the distribution of the last digit of the prices in our data. According to the figure, the digit 9 is the dominant price ending, which is in line with the common retail price setting practice. See Levy et al. (2011), Anderson et al. (2015), and Snir and Levy (2021), and the studies cited therein.

In our data, 9-ending prices comprise more than 90\% of the prices at the EDLP and HiLo stores, similar to price ending distribution patterns Anderson et al. (2015) find in their data. At the HYB store, we find that prices ending with "7” are also common, which is in line with the practice of discount stores, often reported in trade publications. See, for example, Risley (2020).

In Figure C2, we present the distribution of the last two digits of the prices in our data. According to the figure, 99-ending prices are a dominant price feature in our data, also in line with the findings reported in the literature. See, for example, Levy et al. (2011). 


\section{A. Regular Prices}

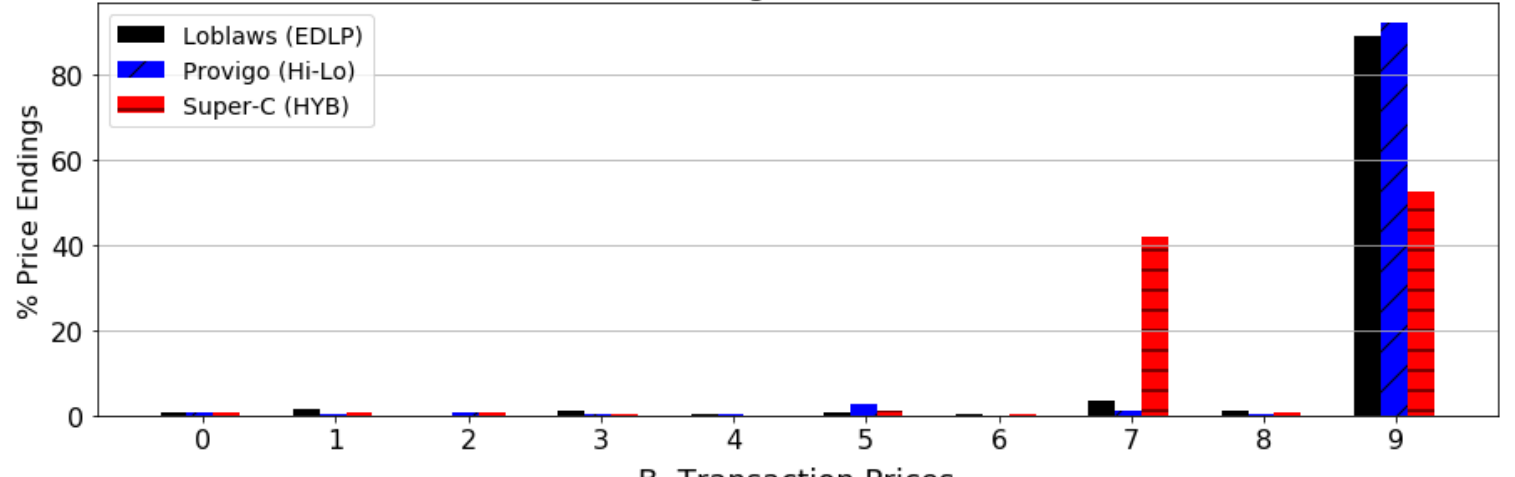

B. Transaction Prices

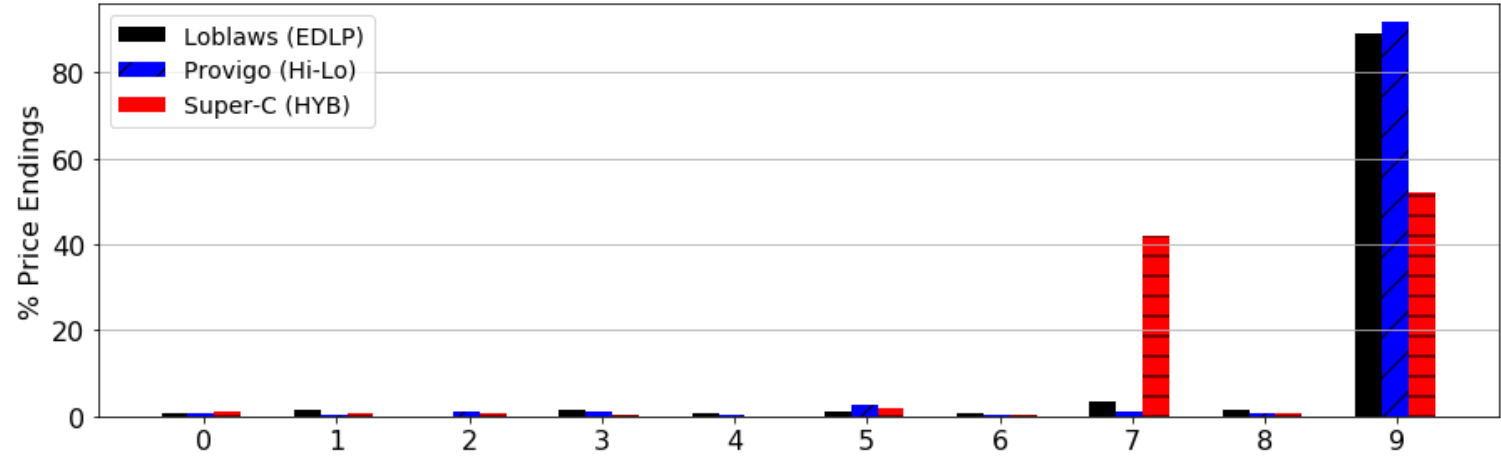

Figure C1. The Distribution of the Right-Most Digits by Store Format 


\section{A. Regular Prices}

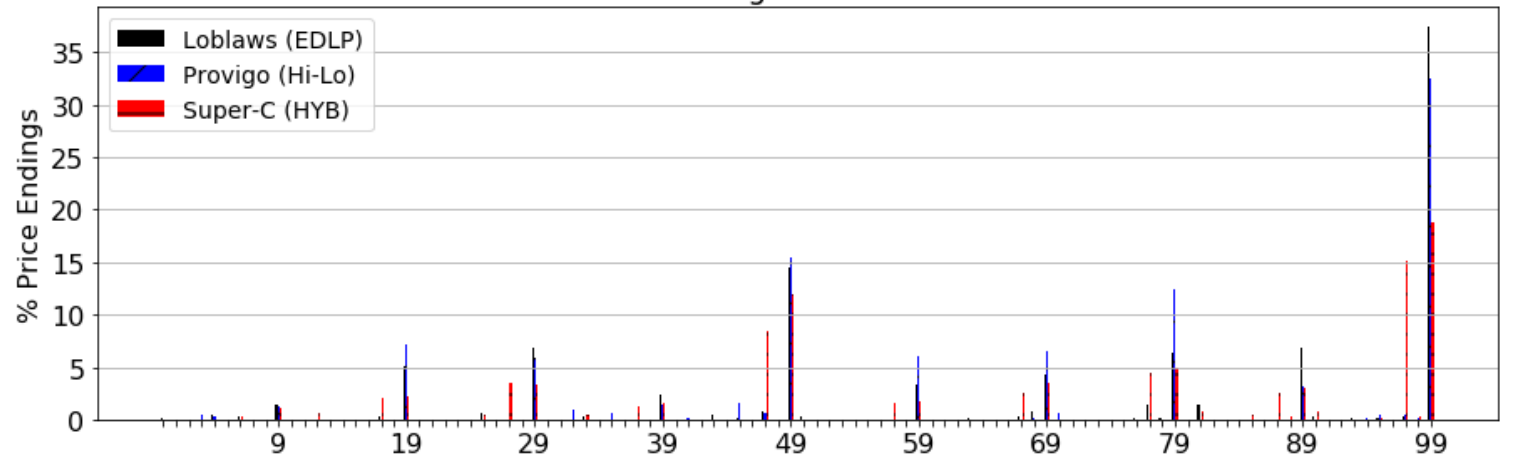

B. Transaction Prices

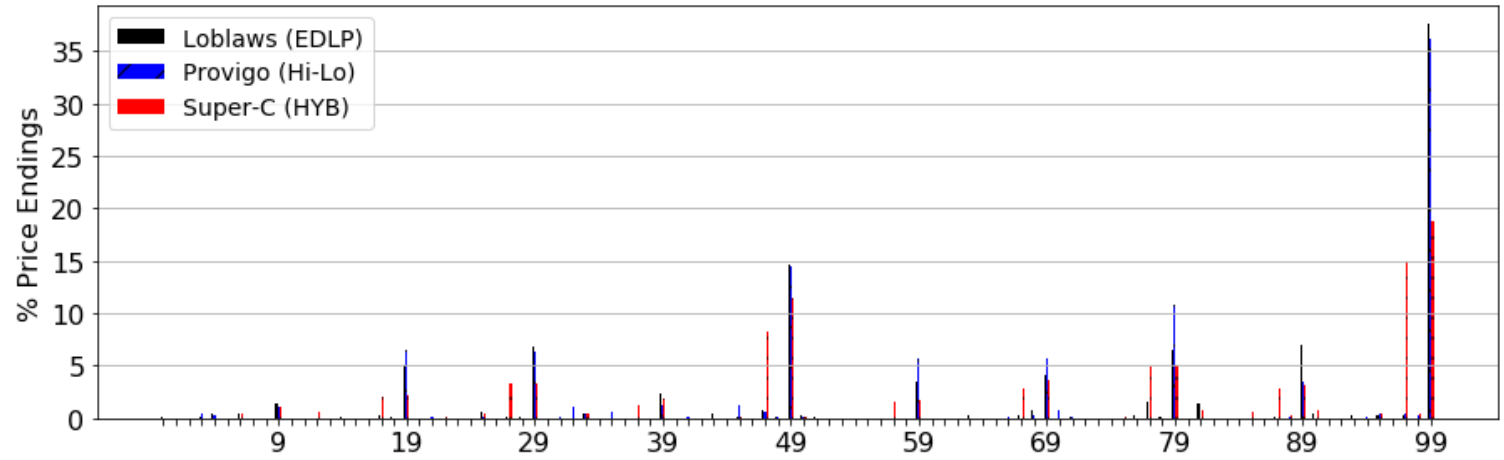

Figure C2. Distribution of the Two Right-Most Digits by Store Format 


\section{Appendix D. Detailed List of Products Sampled and the Corresponding Regular and Transaction Prices}

Table D1. Detailed List of the Products Sampled, by Product Category, by Brand (NB, PL), and by Store Pricing Format, and the Corresponding Average Regular and Transaction Prices

\begin{tabular}{|c|c|c|c|c|c|c|c|}
\hline \multirow[b]{2}{*}{ Product Category } & \multirow[b]{2}{*}{ Product } & \multicolumn{2}{|c|}{ EDLP (Loblaw’s) } & \multicolumn{2}{|c|}{ Hi-Lo (Provigo) } & \multicolumn{2}{|c|}{ HYB (Super-C) } \\
\hline & & $\begin{array}{c}\text { Regular } \\
\text { Price }\end{array}$ & $\begin{array}{c}\text { Transaction } \\
\text { price }\end{array}$ & $\begin{array}{c}\text { Regular } \\
\text { Price }\end{array}$ & $\begin{array}{c}\text { Transaction } \\
\text { price }\end{array}$ & $\begin{array}{c}\text { Regular } \\
\text { Price }\end{array}$ & $\begin{array}{c}\text { Transaction } \\
\text { price }\end{array}$ \\
\hline $\begin{array}{l}\text { Baby Products and } \\
\text { Foods }\end{array}$ & Dove Baby Soap & $\begin{array}{c}1.94 \\
(0.164)\end{array}$ & $\begin{array}{c}1.94 \\
(0.164)\end{array}$ & $\begin{array}{c}2.19 \\
(0.000)\end{array}$ & $\begin{array}{c}2.16 \\
(0.136)\end{array}$ & $\begin{array}{c}1.98 \\
(0.009)\end{array}$ & $\begin{array}{c}1.98 \\
(0.009)\end{array}$ \\
\hline $\begin{array}{l}\text { Baby Products and } \\
\text { Foods }\end{array}$ & Farley's Biscuits 300g & $\begin{array}{c}3.75 \\
(0.159) \\
\end{array}$ & $\begin{array}{c}3.75 \\
(0.159)\end{array}$ & $\begin{array}{c}3.99 \\
(0.002)\end{array}$ & $\begin{array}{c}3.99 \\
(0.002)\end{array}$ & $\begin{array}{c}3.68 \\
(0.010)\end{array}$ & $\begin{array}{c}3.68 \\
(0.010)\end{array}$ \\
\hline $\begin{array}{l}\text { Baby Products and } \\
\text { Foods }\end{array}$ & Heinz Blueberry 213ml & $\begin{array}{c}0.81 \\
(0.000)\end{array}$ & $\begin{array}{c}0.81 \\
(0.000)\end{array}$ & $\begin{array}{c}0.99 \\
(0.000)\end{array}$ & $\begin{array}{c}0.97 \\
(0.065)\end{array}$ & $\begin{array}{c}0.87 \\
(0.000)\end{array}$ & $\begin{array}{c}0.87 \\
(0.000)\end{array}$ \\
\hline $\begin{array}{l}\text { Baby Products and } \\
\text { Foods }\end{array}$ & $\begin{array}{l}\text { Heinz Mixed Cereal } \\
227 \mathrm{~g}\end{array}$ & $\begin{array}{c}2.52 \\
(0.205)\end{array}$ & $\begin{array}{c}2.52 \\
(0.205)\end{array}$ & $\begin{array}{c}2.99 \\
(0.000)\end{array}$ & $\begin{array}{c}2.99 \\
(0.000)\end{array}$ & $\begin{array}{c}2.83 \\
(0.150)\end{array}$ & $\begin{array}{c}2.80 \\
(0.161)\end{array}$ \\
\hline $\begin{array}{l}\text { Baby Products and } \\
\text { Foods }\end{array}$ & $\begin{array}{l}\text { Pablum Soya Cereal } \\
454 \mathrm{~g}\end{array}$ & $\begin{array}{c}0.77 \\
(0.000)\end{array}$ & $\begin{array}{c}0.77 \\
(0.000)\end{array}$ & $\begin{array}{c}1.32 \\
(0.000)\end{array}$ & $\begin{array}{c}1.32 \\
(0.000)\end{array}$ & $\begin{array}{c}0.87 \\
(0.005)\end{array}$ & $\begin{array}{c}0.87 \\
(0.005)\end{array}$ \\
\hline Beverage & Bleue Dry 12x341ml & $\begin{array}{l}15.36 \\
(0.433)\end{array}$ & $\begin{array}{l}15.36 \\
(0.433)\end{array}$ & $\begin{array}{l}15.80 \\
(0.246)\end{array}$ & $\begin{array}{l}15.17 \\
(1.256)\end{array}$ & $\begin{array}{c}15.34 \\
(0.217)\end{array}$ & $\begin{array}{c}15.34 \\
(0.222)\end{array}$ \\
\hline Beverage & Coca-Cola Classic & $\begin{array}{c}1.28 \\
(0.061) \\
\end{array}$ & $\begin{array}{c}1.28 \\
(0.061) \\
\end{array}$ & $\begin{array}{c}1.77 \\
(0.089) \\
\end{array}$ & $\begin{array}{c}1.42 \\
(0.228) \\
\end{array}$ & $\begin{array}{c}1.29 \\
(0.054) \\
\end{array}$ & $\begin{array}{c}1.28 \\
(0.082) \\
\end{array}$ \\
\hline Beverage & $\begin{array}{l}\text { Molson Dry Beer } \\
12 x 341 \mathrm{ml}\end{array}$ & $\begin{array}{l}15.32 \\
(0.541)\end{array}$ & $\begin{array}{l}15.32 \\
(0.541)\end{array}$ & $\begin{array}{l}15.75 \\
(0.252)\end{array}$ & $\begin{array}{l}15.03 \\
(1.260)\end{array}$ & $\begin{array}{l}15.34 \\
(0.217)\end{array}$ & $\begin{array}{l}15.34 \\
(0.222)\end{array}$ \\
\hline Beverage & $\begin{array}{l}\text { Molson Dry Beer } \\
24 \times 341 \mathrm{ml}\end{array}$ & $\begin{array}{c}24.33 \\
(1.079)\end{array}$ & $\begin{array}{c}24.33 \\
(1.079)\end{array}$ & $\begin{array}{c}26.33 \\
(0.236) \\
\end{array}$ & $\begin{array}{c}26.26 \\
(0.519) \\
\end{array}$ & $\begin{array}{c}24.14 \\
(0.933) \\
\end{array}$ & $\begin{array}{c}23.89 \\
(1.060)\end{array}$ \\
\hline Beverage & Montclair 1L & $\begin{array}{c}0.99 \\
(0.052) \\
\end{array}$ & $\begin{array}{c}0.99 \\
(0.052) \\
\end{array}$ & $\begin{array}{c}0.99 \\
(0.000)\end{array}$ & $\begin{array}{c}0.96 \\
(0.057) \\
\end{array}$ & $\begin{array}{c}0.98 \\
(0.010) \\
\end{array}$ & $\begin{array}{c}0.92 \\
(0.091) \\
\end{array}$ \\
\hline Beverage & Pepsi Diet 12x355ml & $\begin{array}{c}4.00 \\
(0.321)\end{array}$ & $\begin{array}{c}4.00 \\
(0.321)\end{array}$ & $\begin{array}{c}4.66 \\
(0.105)\end{array}$ & $\begin{array}{c}4.19 \\
(0.336)\end{array}$ & $\begin{array}{c}4.02 \\
(0.093)\end{array}$ & $\begin{array}{c}3.89 \\
(0.333)\end{array}$ \\
\hline Beverage & Perrier Lemon 750ml & $\begin{array}{c}1.17 \\
(0.056)\end{array}$ & $\begin{array}{c}1.17 \\
(0.060)\end{array}$ & $\begin{array}{c}1.36 \\
(0.045)\end{array}$ & $\begin{array}{c}1.31 \\
(0.138)\end{array}$ & $\begin{array}{c}1.18 \\
(0.010)\end{array}$ & $\begin{array}{c}1.16 \\
(0.058)\end{array}$ \\
\hline Beverage & Sprite 1L & $\begin{array}{c}1.26 \\
(0.217)\end{array}$ & $\begin{array}{c}1.26 \\
(0.217)\end{array}$ & $\begin{array}{c}1.54 \\
(0.050)\end{array}$ & $\begin{array}{c}1.52 \\
(0.152)\end{array}$ & $\begin{array}{c}0.69 \\
(0.000)\end{array}$ & $\begin{array}{c}0.69 \\
(0.026)\end{array}$ \\
\hline Breakfast/Cereals & Alpha Bits 400g & $\begin{array}{c}3.58 \\
(0.353) \\
\end{array}$ & $\begin{array}{c}3.58 \\
(0.353) \\
\end{array}$ & $\begin{array}{c}4.01 \\
(0.078)\end{array}$ & $\begin{array}{c}3.83 \\
(0.443) \\
\end{array}$ & $\begin{array}{c}3.49 \\
(0.000) \\
\end{array}$ & $\begin{array}{c}3.45 \\
(0.124) \\
\end{array}$ \\
\hline Breakfast/Cereals & Cheerios Apple 575g & $\begin{array}{c}4.11 \\
(0.290)\end{array}$ & $\begin{array}{c}4.11 \\
(0.290)\end{array}$ & $\begin{array}{c}5.02 \\
(0.092)\end{array}$ & $\begin{array}{c}4.76 \\
(0.551) \\
\end{array}$ & $\begin{array}{c}4.51 \\
(0.105)\end{array}$ & $\begin{array}{c}4.39 \\
(0.380) \\
\end{array}$ \\
\hline Breakfast/Cereals & $\begin{array}{l}\text { Cheerios Multi-Grain } \\
450 \mathrm{~g}\end{array}$ & $\begin{array}{c}4.13 \\
(0.247)\end{array}$ & $\begin{array}{c}4.13 \\
(0.247)\end{array}$ & $\begin{array}{c}4.77 \\
(0.205)\end{array}$ & $\begin{array}{c}4.58 \\
(0.479)\end{array}$ & $\begin{array}{c}4.52 \\
(0.104)\end{array}$ & $\begin{array}{c}4.41 \\
(0.376)\end{array}$ \\
\hline Breakfast/Cereals & Chex Honey Nut 430g & $\begin{array}{c}3.85 \\
(0.413) \\
\end{array}$ & $\begin{array}{c}3.85 \\
(0.413) \\
\end{array}$ & $\begin{array}{c}4.03 \\
(0.080) \\
\end{array}$ & $\begin{array}{c}3.95 \\
(0.405) \\
\end{array}$ & $\begin{array}{c}4.01 \\
(0.066)\end{array}$ & $\begin{array}{c}3.99 \\
(0.132) \\
\end{array}$ \\
\hline Breakfast/Cereals & Corn Flakes 750g & $\begin{array}{c}3.79 \\
(0.329)\end{array}$ & $\begin{array}{c}3.79 \\
(0.329) \\
\end{array}$ & $\begin{array}{c}4.17 \\
(0.147)\end{array}$ & $\begin{array}{c}4.00 \\
(0.485) \\
\end{array}$ & $\begin{array}{c}3.61 \\
(0.178) \\
\end{array}$ & $\begin{array}{c}3.55 \\
(0.258) \\
\end{array}$ \\
\hline Breakfast/Cereals & Life 730g & $\begin{array}{c}3.89 \\
(0.241)\end{array}$ & $\begin{array}{c}3.89 \\
(0.241)\end{array}$ & $\begin{array}{c}3.99 \\
(0.000)\end{array}$ & $\begin{array}{c}3.89 \\
(0.251)\end{array}$ & $\begin{array}{c}3.94 \\
(0.045)\end{array}$ & $\begin{array}{c}3.75 \\
(0.384)\end{array}$ \\
\hline Breakfast/Cereals & Nesquick Cereal 775g & $\begin{array}{c}6.86 \\
(0.633)\end{array}$ & $\begin{array}{c}6.86 \\
(0.633)\end{array}$ & $\begin{array}{c}7.01 \\
(0.094)\end{array}$ & $\begin{array}{c}6.73 \\
(0.819)\end{array}$ & $\begin{array}{c}6.97 \\
(0.091)\end{array}$ & $\begin{array}{c}6.91 \\
(0.184)\end{array}$ \\
\hline
\end{tabular}




\begin{tabular}{|c|c|c|c|c|c|c|c|}
\hline Breakfast/Cereals & Pops Corn 375g & $\begin{array}{c}3.96 \\
(0.323)\end{array}$ & $\begin{array}{c}3.94 \\
(0.361)\end{array}$ & $\begin{array}{c}4.99 \\
(0.000)\end{array}$ & $\begin{array}{c}4.71 \\
(0.667)\end{array}$ & $\begin{array}{c}3.73 \\
(0.287)\end{array}$ & $\begin{array}{c}3.68 \\
(0.347)\end{array}$ \\
\hline Breakfast/Cereals & Shreddies Cereal 620g & $\begin{array}{c}3.90 \\
(0.190)\end{array}$ & $\begin{array}{c}3.90 \\
(0.190)\end{array}$ & $\begin{array}{c}4.19 \\
(0.000)\end{array}$ & $\begin{array}{c}4.07 \\
(0.343)\end{array}$ & $\begin{array}{c}3.75 \\
(0.242)\end{array}$ & $\begin{array}{c}3.73 \\
(0.283)\end{array}$ \\
\hline Breakfast/Cereals & $\begin{array}{l}\text { Special K Red berries } \\
\text { 350g }\end{array}$ & $\begin{array}{c}4.42 \\
(0.175)\end{array}$ & $\begin{array}{c}4.42 \\
(0.175)\end{array}$ & $\begin{array}{c}4.49 \\
(0.000)\end{array}$ & $\begin{array}{c}4.41 \\
(0.182)\end{array}$ & $\begin{array}{c}4.49 \\
(0.007)\end{array}$ & $\begin{array}{c}4.37 \\
(0.223)\end{array}$ \\
\hline Breakfast/Cereals & Sugar Crisp 400g & $\begin{array}{c}3.58 \\
(0.353)\end{array}$ & $\begin{array}{c}3.58 \\
(0.353)\end{array}$ & $\begin{array}{c}4.18 \\
(0.073)\end{array}$ & $\begin{array}{c}3.96 \\
(0.504)\end{array}$ & $\begin{array}{c}3.49 \\
(0.000)\end{array}$ & $\begin{array}{c}3.45 \\
(0.124)\end{array}$ \\
\hline $\begin{array}{l}\text { Condiments, Sauces } \\
\text { and Spread }\end{array}$ & $\begin{array}{l}\text { Canton Vegetable } \\
\text { Delight 990ml }\end{array}$ & $\begin{array}{c}3.19 \\
(0.261)\end{array}$ & $\begin{array}{c}3.19 \\
(0.261)\end{array}$ & $\begin{array}{c}3.42 \\
(0.193)\end{array}$ & $\begin{array}{c}3.36 \\
(0.234)\end{array}$ & $\begin{array}{c}3.34 \\
(0.091)\end{array}$ & $\begin{array}{c}3.33 \\
(0.118)\end{array}$ \\
\hline $\begin{array}{l}\text { Condiments, Sauces } \\
\text { and Spread }\end{array}$ & $\begin{array}{l}\text { Classics Dressing } \\
\text { 250ml }\end{array}$ & $\begin{array}{c}1.83 \\
(0.177)\end{array}$ & $\begin{array}{c}1.83 \\
(0.177)\end{array}$ & $\begin{array}{c}1.97 \\
(0.040)\end{array}$ & $\begin{array}{c}1.87 \\
(0.259)\end{array}$ & $\begin{array}{c}1.87 \\
(0.059)\end{array}$ & $\begin{array}{c}1.81 \\
(0.179)\end{array}$ \\
\hline $\begin{array}{l}\text { Condiments, Sauces } \\
\text { and Spread }\end{array}$ & $\begin{array}{l}\text { French's Yellow } \\
\text { Mustard 400ml }\end{array}$ & $\begin{array}{c}2.04 \\
(0.153)\end{array}$ & $\begin{array}{c}2.04 \\
(0.153)\end{array}$ & $\begin{array}{c}1.99 \\
(0.000)\end{array}$ & $\begin{array}{c}1.95 \\
(0.160)\end{array}$ & $\begin{array}{c}2.16 \\
(0.068)\end{array}$ & $\begin{array}{c}2.15 \\
(0.087)\end{array}$ \\
\hline $\begin{array}{l}\text { Condiments, Sauces } \\
\text { and Spread }\end{array}$ & $\begin{array}{l}\text { HEINZ Tomato } \\
\text { KETCHUP 1L }\end{array}$ & $\begin{array}{c}3.04 \\
(0.250)\end{array}$ & $\begin{array}{c}3.04 \\
(0.250)\end{array}$ & $\begin{array}{c}3.68 \\
(0.175)\end{array}$ & $\begin{array}{c}3.51 \\
(0.360)\end{array}$ & $\begin{array}{c}3.20 \\
(0.236)\end{array}$ & $\begin{array}{c}3.17 \\
(0.250)\end{array}$ \\
\hline $\begin{array}{l}\text { Condiments, Sauces } \\
\text { and Spread }\end{array}$ & $\begin{array}{l}\text { Hellmann's Mayonaise } \\
1 \mathrm{~L}\end{array}$ & $\begin{array}{c}3.95 \\
(0.243) \\
\end{array}$ & $\begin{array}{c}3.95 \\
(0.243) \\
\end{array}$ & $\begin{array}{c}4.79 \\
(0.000)\end{array}$ & $\begin{array}{c}4.54 \\
(0.589) \\
\end{array}$ & $\begin{array}{c}4.02 \\
(0.116) \\
\end{array}$ & $\begin{array}{c}3.98 \\
(0.231) \\
\end{array}$ \\
\hline $\begin{array}{l}\text { Condiments, Sauces } \\
\text { and Spread }\end{array}$ & $\begin{array}{l}\text { Miracle Whip Dressing } \\
\text { Sauce 1L }\end{array}$ & $\begin{array}{c}3.90 \\
(0.257) \\
\end{array}$ & $\begin{array}{c}3.90 \\
(0.257) \\
\end{array}$ & $\begin{array}{c}4.79 \\
(0.000)\end{array}$ & $\begin{array}{c}4.47 \\
(0.658) \\
\end{array}$ & $\begin{array}{c}3.98 \\
(0.010) \\
\end{array}$ & $\begin{array}{c}3.94 \\
(0.237) \\
\end{array}$ \\
\hline $\begin{array}{l}\text { Condiments, Sauces } \\
\text { and Spread }\end{array}$ & Regular Sugar 2kg & $\begin{array}{c}2.57 \\
(0.064)\end{array}$ & $\begin{array}{c}2.57 \\
(0.064)\end{array}$ & $\begin{array}{c}2.61 \\
(0.054)\end{array}$ & $\begin{array}{c}2.53 \\
(0.215)\end{array}$ & $\begin{array}{c}2.58 \\
(0.010)\end{array}$ & $\begin{array}{c}2.58 \\
(0.042) \\
\end{array}$ \\
\hline $\begin{array}{l}\text { Condiments, Sauces } \\
\text { and Spread }\end{array}$ & Sifto Table Salt 1kg & $\begin{array}{c}1.10 \\
(0.051)\end{array}$ & $\begin{array}{c}1.10 \\
(0.051)\end{array}$ & $\begin{array}{c}1.40 \\
(0.101)\end{array}$ & $\begin{array}{l}1.40 \\
(.101)\end{array}$ & $\begin{array}{c}1.07 \\
(0.036)\end{array}$ & $\begin{array}{c}1.07 \\
(0.038)\end{array}$ \\
\hline $\begin{array}{l}\text { Condiments, Sauces } \\
\text { and Spread }\end{array}$ & VH Soya Sauce $450 \mathrm{ml}$ & $\begin{array}{c}1.47 \\
(0.047)\end{array}$ & $\begin{array}{c}1.47 \\
(0.047)\end{array}$ & $\begin{array}{c}1.64 \\
(0.067)\end{array}$ & $\begin{array}{c}1.59 \\
(0.125)\end{array}$ & $\begin{array}{c}1.48 \\
(0.024)\end{array}$ & $\begin{array}{c}1.47 \\
(0.040)\end{array}$ \\
\hline Dairy Products & $\begin{array}{l}\text { Natrel 1\% Partly } \\
\text { Skimmed Milk 2L }\end{array}$ & $\begin{array}{c}2.85 \\
(0.071)\end{array}$ & $\begin{array}{c}2.85 \\
(0.071)\end{array}$ & $\begin{array}{c}2.84 \\
(0.063)\end{array}$ & $\begin{array}{c}2.84 \\
(0.063)\end{array}$ & $\begin{array}{c}2.84 \\
(0.052)\end{array}$ & $\begin{array}{c}2.84 \\
(0.052)\end{array}$ \\
\hline Dairy Products & Extra Large Eggs 12un & $\begin{array}{c}2.46 \\
(0.115)\end{array}$ & $\begin{array}{c}2.46 \\
(0.115)\end{array}$ & $\begin{array}{c}2.52 \\
(0.082)\end{array}$ & $\begin{array}{c}2.52 \\
(0.082)\end{array}$ & $\begin{array}{c}2.48 \\
(0.028)\end{array}$ & $\begin{array}{c}2.47 \\
(0.049)\end{array}$ \\
\hline Dairy Products & $\begin{array}{l}\text { Lactantia 2\% Skimmed } \\
\text { Milk 2L }\end{array}$ & $\begin{array}{c}3.01 \\
(0.030)\end{array}$ & $\begin{array}{c}3.01 \\
(0.030)\end{array}$ & $\begin{array}{c}3.00 \\
(0.056)\end{array}$ & $\begin{array}{c}3.00 \\
(0.056)\end{array}$ & $\begin{array}{c}2.94 \\
(0.041)\end{array}$ & $\begin{array}{c}2.94 \\
(0.041) \\
\end{array}$ \\
\hline Dairy Products & Lactantia Butter 454g & $\begin{array}{c}3.89 \\
(0.243) \\
\end{array}$ & $\begin{array}{c}3.89 \\
(0.243) \\
\end{array}$ & $\begin{array}{c}4.15 \\
(0.168) \\
\end{array}$ & $\begin{array}{c}4.07 \\
(0.287) \\
\end{array}$ & $\begin{array}{c}3.95 \\
(0.073) \\
\end{array}$ & $\begin{array}{c}3.85 \\
(0.219) \\
\end{array}$ \\
\hline Dairy Products & Large Eggs 12un & $\begin{array}{c}1.92 \\
(0.302)\end{array}$ & $\begin{array}{c}1.92 \\
(0.302)\end{array}$ & $\begin{array}{c}2.40 \\
(0.100)\end{array}$ & $\begin{array}{c}2.35 \\
(0.236)\end{array}$ & $\begin{array}{c}1.96 \\
(0.181)\end{array}$ & $\begin{array}{c}1.89 \\
(0.298) \\
\end{array}$ \\
\hline Dairy Products & Omega Eggs 12un & $\begin{array}{c}3.20 \\
(0.063)\end{array}$ & $\begin{array}{c}3.20 \\
(0.063)\end{array}$ & $\begin{array}{c}3.23 \\
(0.081)\end{array}$ & $\begin{array}{c}3.22 \\
(0.100)\end{array}$ & $\begin{array}{c}3.15 \\
(0.050)\end{array}$ & $\begin{array}{c}3.12 \\
(0.071)\end{array}$ \\
\hline Dairy Products & $\begin{array}{l}\text { P'tit Quebec Cheese } \\
600 \mathrm{~g}\end{array}$ & $\begin{array}{c}6.32 \\
(0.943)\end{array}$ & $\begin{array}{c}6.27 \\
(0.977)\end{array}$ & $\begin{array}{c}7.04 \\
(0.134)\end{array}$ & $\begin{array}{c}6.74 \\
(0.825)\end{array}$ & $\begin{array}{c}6.59 \\
(0.143)\end{array}$ & $\begin{array}{c}6.37 \\
(0.762)\end{array}$ \\
\hline Dairy Products & $\begin{array}{l}\text { Quebon 3.25\% Bottle } \\
\text { Milk 2L }\end{array}$ & $\begin{array}{c}3.02 \\
(0.033)\end{array}$ & $\begin{array}{c}3.02 \\
(0.033)\end{array}$ & $\begin{array}{c}3.00 \\
(0.030)\end{array}$ & $\begin{array}{c}3.00 \\
(0.030)\end{array}$ & $\begin{array}{c}3.02 \\
(0.034)\end{array}$ & $\begin{array}{c}3.02 \\
(0.034)\end{array}$ \\
\hline Dairy Products & Saputo Cheese 700g & $\begin{array}{c}7.28 \\
(0.279)\end{array}$ & $\begin{array}{c}7.28 \\
(0.279)\end{array}$ & $\begin{array}{c}7.51 \\
(0.071)\end{array}$ & $\begin{array}{c}7.46 \\
(0.174)\end{array}$ & $\begin{array}{c}7.12 \\
(0.166)\end{array}$ & $\begin{array}{c}6.97 \\
(0.337)\end{array}$ \\
\hline Dairy Products & Soya 1.89L & $\begin{array}{c}3.93 \\
(0.080)\end{array}$ & $\begin{array}{c}3.93 \\
(0.080)\end{array}$ & $\begin{array}{c}3.95 \\
(0.053)\end{array}$ & $\begin{array}{c}3.87 \\
(0.191)\end{array}$ & $\begin{array}{c}3.98 \\
(0.096)\end{array}$ & $\begin{array}{c}3.96 \\
(0.122)\end{array}$ \\
\hline Frozen Food & $\begin{array}{l}\text { Arctic Garden } \\
\text { California Style 2kg }\end{array}$ & $\begin{array}{c}6.13 \\
(0.151) \\
\end{array}$ & $\begin{array}{c}6.13 \\
(0.151) \\
\end{array}$ & $\begin{array}{c}6.91 \\
(0.160) \\
\end{array}$ & $\begin{array}{c}6.91 \\
(0.160) \\
\end{array}$ & $\begin{array}{c}6.26 \\
(0.185) \\
\end{array}$ & $\begin{array}{c}6.26 \\
(0.185) \\
\end{array}$ \\
\hline Frozen Food & $\begin{array}{l}\text { Arctic Garden Thai } \\
\text { Style } 1.75 \mathrm{~kg}\end{array}$ & $\begin{array}{c}6.77 \\
(0.288)\end{array}$ & $\begin{array}{c}6.77 \\
(0.288)\end{array}$ & $\begin{array}{c}7.23 \\
(0.124)\end{array}$ & $\begin{array}{c}7.23 \\
(0.124)\end{array}$ & $\begin{array}{c}6.76 \\
(0.295)\end{array}$ & $\begin{array}{c}6.76 \\
(0.295) \\
\end{array}$ \\
\hline Frozen Food & Delissio Pizza 840g & $\begin{array}{c}7.12 \\
(0.813)\end{array}$ & $\begin{array}{c}7.12 \\
(0.813)\end{array}$ & $\begin{array}{c}8.81 \\
(0.060)\end{array}$ & $\begin{array}{c}8.19 \\
(1.270)\end{array}$ & $\begin{array}{c}7.49 \\
(0.008)\end{array}$ & $\begin{array}{c}7.41 \\
(0.518)\end{array}$ \\
\hline Frozen Food & 6 Eggs 312g & $\begin{array}{c}2.21 \\
(0.106)\end{array}$ & $\begin{array}{c}2.20 \\
(0.130)\end{array}$ & $\begin{array}{c}2.50 \\
(0.024)\end{array}$ & $\begin{array}{c}2.37 \\
(0.251)\end{array}$ & $\begin{array}{c}2.24 \\
(0.040)\end{array}$ & $\begin{array}{c}2.21 \\
(0.107)\end{array}$ \\
\hline Frozen Food & Minis Ice Cream 100ml & $\begin{array}{c}0.67 \\
(0.044)\end{array}$ & $\begin{array}{c}0.67 \\
(0.044)\end{array}$ & $\begin{array}{c}0.70 \\
(0.008)\end{array}$ & $\begin{array}{c}0.68 \\
(0.052)\end{array}$ & $\begin{array}{c}0.80 \\
(0.037)\end{array}$ & $\begin{array}{c}0.78 \\
(0.070)\end{array}$ \\
\hline
\end{tabular}




\begin{tabular}{|c|c|c|c|c|c|c|c|}
\hline Frozen Food & Nestle Parlour 2L & $\begin{array}{c}3.87 \\
(0.482)\end{array}$ & $\begin{array}{c}3.87 \\
(0.482)\end{array}$ & $\begin{array}{c}4.73 \\
(0.060)\end{array}$ & $\begin{array}{c}4.45 \\
(.605)\end{array}$ & $\begin{array}{c}4.43 \\
(0.090)\end{array}$ & $\begin{array}{c}4.33 \\
(0.294)\end{array}$ \\
\hline Frozen Food & Quebon Classic 2L & $\begin{array}{c}4.56 \\
(0.489)\end{array}$ & $\begin{array}{c}4.56 \\
(0.489)\end{array}$ & $\begin{array}{c}4.92 \\
(0.047)\end{array}$ & $\begin{array}{c}4.87 \\
(0.340)\end{array}$ & $\begin{array}{c}3.96 \\
(0.172)\end{array}$ & $\begin{array}{c}3.68 \\
(0.459)\end{array}$ \\
\hline $\begin{array}{l}\text { Health \& Beauty } \\
\text { Aid }\end{array}$ & $\begin{array}{l}\text { Alberto Hairspray } \\
\text { 300ml }\end{array}$ & $\begin{array}{c}2.66 \\
(0.240)\end{array}$ & $\begin{array}{c}2.57 \\
(0.310)\end{array}$ & $\begin{array}{c}2.79 \\
(0.368)\end{array}$ & $\begin{array}{c}2.79 \\
(0.370)\end{array}$ & $\begin{array}{c}2.89 \\
(0.008)\end{array}$ & $\begin{array}{c}2.89 \\
(0.008)\end{array}$ \\
\hline $\begin{array}{l}\text { Health \& Beauty } \\
\text { Aid }\end{array}$ & Colgate Total 75ml & $\begin{array}{c}1.49 \\
(0.002)\end{array}$ & $\begin{array}{c}1.49 \\
(0.002)\end{array}$ & $\begin{array}{c}1.77 \\
(0.058) \\
\end{array}$ & $\begin{array}{c}1.76 \\
(0.077) \\
\end{array}$ & $\begin{array}{c}1.57 \\
(0.034) \\
\end{array}$ & $\begin{array}{c}1.54 \\
(0.084)\end{array}$ \\
\hline $\begin{array}{l}\text { Health \& Beauty } \\
\text { Aid }\end{array}$ & Dove All Day 354ml & $\begin{array}{c}4.85 \\
(0.124) \\
\end{array}$ & $\begin{array}{c}4.81 \\
(0.285) \\
\end{array}$ & $\begin{array}{c}4.92 \\
(0.304) \\
\end{array}$ & $\begin{array}{c}4.92 \\
(0.304) \\
\end{array}$ & $\begin{array}{c}4.90 \\
(0.186) \\
\end{array}$ & $\begin{array}{r}4.85 \\
(0.200) \\
\end{array}$ \\
\hline $\begin{array}{l}\text { Health \& Beauty } \\
\text { Aid }\end{array}$ & Dove Soap 2x100g & $\begin{array}{c}1.98 \\
(0.198)\end{array}$ & $\begin{array}{c}1.98 \\
(0.198)\end{array}$ & $\begin{array}{c}2.37 \\
(0.144)\end{array}$ & $\begin{array}{c}2.29 \\
(0.213)\end{array}$ & $\begin{array}{c}1.97 \\
(0.050)\end{array}$ & $\begin{array}{c}1.96 \\
(0.060)\end{array}$ \\
\hline $\begin{array}{l}\text { Health \& Beauty } \\
\text { Aid }\end{array}$ & $\begin{array}{l}\text { Finesse Extra Body } \\
\text { Shampoo 300ml }\end{array}$ & $\begin{array}{c}1.89 \\
(0.111)\end{array}$ & $\begin{array}{c}1.89 \\
(0.111)\end{array}$ & $\begin{array}{c}2.90 \\
(0.258)\end{array}$ & $\begin{array}{c}2.90 \\
(0.258)\end{array}$ & $\begin{array}{c}2.86 \\
(0.247)\end{array}$ & $\begin{array}{c}2.79 \\
(0.360)\end{array}$ \\
\hline $\begin{array}{l}\text { Health \& Beauty } \\
\text { Aid }\end{array}$ & Fructis Style 300ml & $\begin{array}{c}3.06 \\
(0.251) \\
\end{array}$ & $\begin{array}{c}2.95 \\
(0.429) \\
\end{array}$ & $\begin{array}{c}3.16 \\
(0.200) \\
\end{array}$ & $\begin{array}{c}3.11 \\
(0.172) \\
\end{array}$ & $\begin{array}{c}3.35 \\
(0.250) \\
\end{array}$ & $\begin{array}{c}3.31 \\
(0.280) \\
\end{array}$ \\
\hline $\begin{array}{l}\text { Health \& Beauty } \\
\text { Aid }\end{array}$ & $\begin{array}{l}\text { Gillette Shaving Cream } \\
60 \mathrm{~g}\end{array}$ & $\begin{array}{c}3.20 \\
(0.120)\end{array}$ & $\begin{array}{c}3.20 \\
(0.120)\end{array}$ & $\begin{array}{c}3.91 \\
(0.181)\end{array}$ & $\begin{array}{c}3.87 \\
(0.235)\end{array}$ & $\begin{array}{c}3.29 \\
(0.008)\end{array}$ & $\begin{array}{c}3.25 \\
(0.153)\end{array}$ \\
\hline $\begin{array}{l}\text { Health \& Beauty } \\
\text { Aid }\end{array}$ & $\begin{array}{l}\text { Head \& Shoulder } \\
400 \mathrm{ml}\end{array}$ & $\begin{array}{c}5.30 \\
(0.078)\end{array}$ & $\begin{array}{c}5.06 \\
(0.547)\end{array}$ & $\begin{array}{c}5.48 \\
(0.254)\end{array}$ & $\begin{array}{c}5.45 \\
(0.268)\end{array}$ & $\begin{array}{c}5.42 \\
(0.086)\end{array}$ & $\begin{array}{c}5.38 \\
(0.142)\end{array}$ \\
\hline $\begin{array}{l}\text { Health \& Beauty } \\
\text { Aid }\end{array}$ & $\begin{array}{l}\text { Pantene Shampoo } \\
400 \mathrm{ml}\end{array}$ & $\begin{array}{c}4.59 \\
(0.265)\end{array}$ & $\begin{array}{c}4.39 \\
(0.489)\end{array}$ & $\begin{array}{c}4.80 \\
(0.408)\end{array}$ & $\begin{array}{c}4.80 \\
(0.412)\end{array}$ & $\begin{array}{c}4.91 \\
(0.054)\end{array}$ & $\begin{array}{c}4.86 \\
(0.150) \\
\end{array}$ \\
\hline $\begin{array}{l}\text { Health \& Beauty } \\
\text { Aid }\end{array}$ & $\begin{array}{l}\text { Scope Mouthwash } \\
\text { Original Mint 1L }\end{array}$ & $\begin{array}{c}3.73 \\
(0.156) \\
\end{array}$ & $\begin{array}{c}3.73 \\
(0.156) \\
\end{array}$ & $\begin{array}{c}4.00 \\
(0.419) \\
\end{array}$ & $\begin{array}{c}3.99 \\
(0.441) \\
\end{array}$ & $\begin{array}{c}3.86 \\
(0.099) \\
\end{array}$ & $\begin{array}{c}3.86 \\
(0.099) \\
\end{array}$ \\
\hline Households & Arctic Power 3.3kg & $\begin{array}{c}6.66 \\
(0.556) \\
\end{array}$ & $\begin{array}{c}6.66 \\
(0.556)\end{array}$ & $\begin{array}{c}8.49 \\
(0.000)\end{array}$ & $\begin{array}{c}8.34 \\
(0.590) \\
\end{array}$ & $\begin{array}{c}6.85 \\
(0.530) \\
\end{array}$ & $\begin{array}{c}6.80 \\
(0.665) \\
\end{array}$ \\
\hline Households & $\begin{array}{l}\text { Canola Harvest Oil } \\
1.89 \mathrm{~L}\end{array}$ & $\begin{array}{c}4.80 \\
(0.523)\end{array}$ & $\begin{array}{c}4.80 \\
(0.523)\end{array}$ & $\begin{array}{c}5.45 \\
(0.250)\end{array}$ & $\begin{array}{c}5.32 \\
(0.491)\end{array}$ & $\begin{array}{c}4.60 \\
(0.498)\end{array}$ & $\begin{array}{c}4.58 \\
(0.502)\end{array}$ \\
\hline Households & Downy April Fresh 3L & $\begin{array}{c}5.58 \\
(0.157)\end{array}$ & $\begin{array}{c}5.58 \\
(0.157)\end{array}$ & $\begin{array}{c}6.74 \\
(0.115)\end{array}$ & $\begin{array}{c}6.64 \\
(0.279)\end{array}$ & $\begin{array}{c}5.68 \\
(.010)\end{array}$ & $\begin{array}{c}5.67 \\
(0.038)\end{array}$ \\
\hline Households & Five Rose Flour 2.5kg & $\begin{array}{c}3.97 \\
(0.139)\end{array}$ & $\begin{array}{c}3.97 \\
(0.139)\end{array}$ & $\begin{array}{c}4.00 \\
(0.058)\end{array}$ & $\begin{array}{c}3.93 \\
(0.188)\end{array}$ & $\begin{array}{c}4.32 \\
(0.056)\end{array}$ & $\begin{array}{c}4.32 \\
(0.057)\end{array}$ \\
\hline Households & Fleecy FreshAir 5L & $\begin{array}{c}4.97 \\
(0.539)\end{array}$ & $\begin{array}{c}4.97 \\
(0.539)\end{array}$ & $\begin{array}{c}6.01 \\
(0.065)\end{array}$ & $\begin{array}{c}5.89 \\
(0.479)\end{array}$ & $\begin{array}{c}5.17 \\
(0.138)\end{array}$ & $\begin{array}{c}5.14 \\
(0.161)\end{array}$ \\
\hline Households & $\begin{array}{l}\text { Mazola Corn Cooking } \\
\text { Oil 2L }\end{array}$ & $\begin{array}{c}5.01 \\
(0.349)\end{array}$ & $\begin{array}{c}5.01 \\
(0.349)\end{array}$ & $\begin{array}{c}6.08 \\
(0.191)\end{array}$ & $\begin{array}{c}5.91 \\
(0.518)\end{array}$ & $\begin{array}{c}5.71 \\
(0.239)\end{array}$ & $\begin{array}{c}5.38 \\
(0.459) \\
\end{array}$ \\
\hline Households & $\begin{array}{l}\text { Palmolive Dishwashing } \\
\text { Liquid 625L }\end{array}$ & $\begin{array}{c}2.00 \\
(0.047)\end{array}$ & $\begin{array}{c}2.00 \\
(0.047)\end{array}$ & $\begin{array}{c}2.62 \\
(0.045) \\
\end{array}$ & $\begin{array}{c}2.54 \\
(0.236) \\
\end{array}$ & $\begin{array}{c}1.98 \\
(0.010) \\
\end{array}$ & $\begin{array}{c}1.98 \\
(0.010) \\
\end{array}$ \\
\hline Households & Purex 3.78L & $\begin{array}{c}5.83 \\
(0.165)\end{array}$ & $\begin{array}{c}5.83 \\
(0.165)\end{array}$ & $\begin{array}{c}8.02 \\
(0.069)\end{array}$ & $\begin{array}{c}7.98 \\
(0.211)\end{array}$ & $\begin{array}{c}5.78 \\
(0.010)\end{array}$ & $\begin{array}{c}5.78 \\
(0.010)\end{array}$ \\
\hline Households & Robin Hood Flour 10kg & $\begin{array}{c}7.99 \\
(0.000)\end{array}$ & $\begin{array}{c}7.99 \\
(0.000)\end{array}$ & $\begin{array}{c}8.16 \\
(0.484)\end{array}$ & $\begin{array}{c}8.05 \\
(0.784)\end{array}$ & $\begin{array}{c}6.59 \\
(0.689)\end{array}$ & $\begin{array}{c}6.26 \\
(0.827)\end{array}$ \\
\hline Households & $\begin{array}{l}\text { Sunlight Detergent with } \\
\text { bleach } 3.3 \mathrm{~kg}\end{array}$ & $\begin{array}{c}7.79 \\
(0.417) \\
\end{array}$ & $\begin{array}{c}7.79 \\
(0.417) \\
\end{array}$ & $\begin{array}{c}8.99 \\
(0.000) \\
\end{array}$ & $\begin{array}{c}8.78 \\
(0.800) \\
\end{array}$ & $\begin{array}{c}6.91 \\
(0.193) \\
\end{array}$ & $\begin{array}{c}6.90 \\
(0.202) \\
\end{array}$ \\
\hline Households & $\begin{array}{l}\text { Sunlight Dishwashing } \\
\text { Liquid 750ml }\end{array}$ & $\begin{array}{c}1.85 \\
(0.054)\end{array}$ & $\begin{array}{c}1.85 \\
(0.054)\end{array}$ & $\begin{array}{c}2.48 \\
(0.039)\end{array}$ & $\begin{array}{c}2.45 \\
(0.100)\end{array}$ & $\begin{array}{c}1.97 \\
(0.047)\end{array}$ & $\begin{array}{c}1.95 \\
(0.080)\end{array}$ \\
\hline Households & $\begin{array}{l}\text { Tide Detergent Power } \\
3.4 \mathrm{~kg}\end{array}$ & $\begin{array}{c}8.41 \\
(0.281)\end{array}$ & $\begin{array}{c}8.41 \\
(0.281)\end{array}$ & $\begin{array}{c}9.99 \\
(0.000)\end{array}$ & $\begin{array}{c}9.72 \\
(0.792)\end{array}$ & $\begin{array}{c}8.53 \\
(0.113)\end{array}$ & $\begin{array}{c}8.46 \\
(0.379)\end{array}$ \\
\hline Juices & Del Monte 1L & $\begin{array}{c}1.12 \\
(0.119)\end{array}$ & $\begin{array}{c}1.12 \\
(0.119)\end{array}$ & $\begin{array}{c}1.21 \\
(0.086)\end{array}$ & $\begin{array}{c}1.15 \\
(0.161)\end{array}$ & $\begin{array}{c}1.16 \\
(0.062)\end{array}$ & $\begin{array}{c}1.14 \\
(0.078)\end{array}$ \\
\hline Juices & Oasis Classic 960ml & $\begin{array}{c}1.23 \\
(0.168) \\
\end{array}$ & $\begin{array}{c}1.23 \\
(0.168) \\
\end{array}$ & $\begin{array}{c}1.41 \\
(0.141)\end{array}$ & $\begin{array}{c}1.29 \\
(0.241) \\
\end{array}$ & $\begin{array}{c}1.25 \\
(0.083) \\
\end{array}$ & $\begin{array}{c}1.19 \\
(0.137) \\
\end{array}$ \\
\hline Juices & $\begin{array}{l}\text { Ocean Spray Cocktail } \\
1.89 \mathrm{~L}\end{array}$ & $\begin{array}{c}3.69 \\
(0.028) \\
\end{array}$ & $\begin{array}{c}3.69 \\
(0.028) \\
\end{array}$ & $\begin{array}{c}3.79 \\
(0.028) \\
\end{array}$ & $\begin{array}{c}3.73 \\
(0.158) \\
\end{array}$ & $\begin{array}{c}3.68 \\
(0.010) \\
\end{array}$ & $\begin{array}{c}3.62 \\
(0.193) \\
\end{array}$ \\
\hline Juices & Rougemont 1.89L & $\begin{array}{c}2.57 \\
(0.092)\end{array}$ & $\begin{array}{c}2.57 \\
(0.092)\end{array}$ & $\begin{array}{c}2.59 \\
(0.000)\end{array}$ & $\begin{array}{c}2.57 \\
(0.153)\end{array}$ & $\begin{array}{c}2.39 \\
(0.023)\end{array}$ & $\begin{array}{c}2.39 \\
(0.023)\end{array}$ \\
\hline
\end{tabular}




\begin{tabular}{|c|c|c|c|c|c|c|c|}
\hline Juices & $\begin{array}{l}\text { Tropicana Orange Juice } \\
\text { 1.89L }\end{array}$ & $\begin{array}{c}3.40 \\
(0.283)\end{array}$ & $\begin{array}{c}3.40 \\
(0.283)\end{array}$ & $\begin{array}{c}3.49 \\
(0.028)\end{array}$ & $\begin{array}{c}3.38 \\
(0.256)\end{array}$ & $\begin{array}{c}3.44 \\
(0.107)\end{array}$ & $\begin{array}{c}3.39 \\
(0.165)\end{array}$ \\
\hline Juices & Welch's Fruit 1.82L & $\begin{array}{c}4.52 \\
(0.076)\end{array}$ & $\begin{array}{c}4.52 \\
(0.076)\end{array}$ & $\begin{array}{c}4.59 \\
(0.059)\end{array}$ & $\begin{array}{c}4.50 \\
(0.210)\end{array}$ & $\begin{array}{c}4.50 \\
(0.068)\end{array}$ & $\begin{array}{c}4.39 \\
(0.219)\end{array}$ \\
\hline $\begin{array}{l}\text { Paper Towel, Tissue } \\
\& \text { Pet Supplies }\end{array}$ & Cat Chow 4kg & $\begin{array}{c}10.09 \\
(0.198)\end{array}$ & $\begin{array}{c}10.09 \\
(0.198)\end{array}$ & $\begin{array}{c}10.95 \\
(0.135)\end{array}$ & $\begin{array}{l}10.95 \\
(0.135)\end{array}$ & $\begin{array}{c}9.98 \\
(0.010)\end{array}$ & $\begin{array}{c}9.96 \\
(0.098)\end{array}$ \\
\hline $\begin{array}{l}\text { Paper Towel, Tissue } \\
\text { \& Pet Supplies }\end{array}$ & $\begin{array}{l}\text { Cottonolle Paper Towel } \\
\text { 30RL }\end{array}$ & $\begin{array}{c}13.95 \\
(0.277)\end{array}$ & $\begin{array}{c}13.95 \\
(0.277)\end{array}$ & $\begin{array}{c}13.76 \\
(0.645)\end{array}$ & $\begin{array}{l}13.76 \\
(0.645)\end{array}$ & $\begin{array}{c}9.02 \\
(0.118)\end{array}$ & $\begin{array}{c}8.96 \\
(0.339) \\
\end{array}$ \\
\hline $\begin{array}{l}\text { Paper Towel, Tissue } \\
\text { \& Pet Supplies }\end{array}$ & Dog Chow 2kg & $\begin{array}{c}4.99 \\
(0.000)\end{array}$ & $\begin{array}{c}4.99 \\
(0.000)\end{array}$ & $\begin{array}{c}5.38 \\
(0.191)\end{array}$ & $\begin{array}{c}5.28 \\
(0.278)\end{array}$ & $\begin{array}{c}4.98 \\
(0.010)\end{array}$ & $\begin{array}{c}4.98 \\
(0.010)\end{array}$ \\
\hline $\begin{array}{l}\text { Paper Towel, Tissue } \\
\text { \& Pet Supplies }\end{array}$ & Kleenex Tissue 230FE & $\begin{array}{c}2.45 \\
(0.146)\end{array}$ & $\begin{array}{c}2.45 \\
(0.146)\end{array}$ & $\begin{array}{c}2.79 \\
(0.000)\end{array}$ & $\begin{array}{c}2.77 \\
(0.065)\end{array}$ & $\begin{array}{c}2.58 \\
(0.010)\end{array}$ & $\begin{array}{c}2.57 \\
(0.046)\end{array}$ \\
\hline $\begin{array}{l}\text { Paper Towel, Tissue } \\
\& \text { Pet Supplies }\end{array}$ & $\begin{array}{l}\text { Puffs Plus Lotion } \\
\text { 144FE }\end{array}$ & $\begin{array}{c}2.55 \\
(0.102) \\
\end{array}$ & $\begin{array}{c}2.55 \\
(0.102) \\
\end{array}$ & $\begin{array}{c}2.89 \\
(0.000) \\
\end{array}$ & $\begin{array}{c}2.86 \\
(0.097) \\
\end{array}$ & $\begin{array}{c}2.48 \\
(0.010) \\
\end{array}$ & $\begin{array}{c}2.45 \\
(0.087) \\
\end{array}$ \\
\hline $\begin{array}{l}\text { Paper Towel, Tissue } \\
\text { \& Pet Supplies }\end{array}$ & Puppy Chow 8kg & $\begin{array}{c}11.06 \\
(0.172)\end{array}$ & $\begin{array}{c}11.06 \\
(0.172)\end{array}$ & $\begin{array}{c}14.26 \\
(0.598)\end{array}$ & $\begin{array}{l}14.10 \\
(0.813)\end{array}$ & $\begin{array}{l}11.47 \\
(0.009)\end{array}$ & $\begin{array}{l}11.45 \\
(0.097) \\
\end{array}$ \\
\hline $\begin{array}{l}\text { Paper Towel, Tissue } \\
\text { \& Pet Supplies }\end{array}$ & Scotties Tissue $150 \mathrm{FE}$ & $\begin{array}{c}0.99 \\
(0.014)\end{array}$ & $\begin{array}{c}0.99 \\
(0.014)\end{array}$ & $\begin{array}{c}1.24 \\
(0.050)\end{array}$ & $\begin{array}{c}1.20 \\
(0.111)\end{array}$ & $\begin{array}{c}0.99 \\
(0.000)\end{array}$ & $\begin{array}{c}0.99 \\
(0.000)\end{array}$ \\
\hline $\begin{array}{l}\text { Soup / Canned } \\
\text { Foods }\end{array}$ & $\begin{array}{l}\text { Aylmer Whole Tomato } \\
796 \mathrm{ml}\end{array}$ & $\begin{array}{c}1.29 \\
(0.000) \\
\end{array}$ & $\begin{array}{c}1.29 \\
(0.000) \\
\end{array}$ & $\begin{array}{c}1.42 \\
(0.062) \\
\end{array}$ & $\begin{array}{c}1.31 \\
(0.218) \\
\end{array}$ & $\begin{array}{c}1.28 \\
(0.010) \\
\end{array}$ & $\begin{array}{c}1.26 \\
(0.090) \\
\end{array}$ \\
\hline $\begin{array}{l}\text { Soup / Canned } \\
\text { Foods }\end{array}$ & $\begin{array}{l}\text { Del Monte Fruit } \\
\text { Cocktail } 796 \mathrm{ml}\end{array}$ & $\begin{array}{c}2.72 \\
(0.184)\end{array}$ & $\begin{array}{c}2.72 \\
(0.184)\end{array}$ & $\begin{array}{c}2.93 \\
(0.093)\end{array}$ & $\begin{array}{c}2.86 \\
(0.211)\end{array}$ & $\begin{array}{c}2.75 \\
(0.153)\end{array}$ & $\begin{array}{c}2.73 \\
(0.164)\end{array}$ \\
\hline $\begin{array}{l}\text { Soup / Canned } \\
\text { Foods }\end{array}$ & $\begin{array}{l}\text { Green Giant Beans } \\
\text { 398ml }\end{array}$ & $\begin{array}{c}1.03 \\
(0.164) \\
\end{array}$ & $\begin{array}{c}1.03 \\
(0.164) \\
\end{array}$ & $\begin{array}{c}1.17 \\
(0.054)\end{array}$ & $\begin{array}{c}1.13 \\
(0.140) \\
\end{array}$ & $\begin{array}{c}1.15 \\
(0.076)\end{array}$ & $\begin{array}{c}1.09 \\
(0.123) \\
\end{array}$ \\
\hline $\begin{array}{l}\text { Soup / Canned } \\
\text { Foods } \\
\end{array}$ & $\begin{array}{l}\text { Pastene Diced Tomato } \\
\text { 796ml }\end{array}$ & $\begin{array}{c}1.42 \\
(0.054)\end{array}$ & $\begin{array}{c}1.42 \\
(0.054)\end{array}$ & $\begin{array}{c}1.59 \\
(0.000) \\
\end{array}$ & $\begin{array}{c}1.55 \\
(0.119) \\
\end{array}$ & $\begin{array}{c}1.35 \\
(0.082) \\
\end{array}$ & $\begin{array}{c}1.31 \\
(.110)\end{array}$ \\
\hline \multicolumn{8}{|c|}{ B. Private Label Products } \\
\hline & & \multicolumn{2}{|c|}{ EDLP (Loblaw’s) } & \multicolumn{2}{|c|}{ Hi-Lo (Provigo) } & \multicolumn{2}{|c|}{ HYB (Super-C) } \\
\hline Product Category & Product & $\begin{array}{c}\text { Regular } \\
\text { Price }\end{array}$ & $\begin{array}{c}\text { Transaction } \\
\text { price }\end{array}$ & $\begin{array}{c}\text { Regular } \\
\text { Price }\end{array}$ & $\begin{array}{c}\text { Transaction } \\
\text { price }\end{array}$ & $\begin{array}{c}\text { Regular } \\
\text { Price }\end{array}$ & $\begin{array}{c}\text { Transaction } \\
\text { price }\end{array}$ \\
\hline Beverage & $\begin{array}{l}\text { PC Natural Spring } \\
\text { Water 1.5L }\end{array}$ & $\begin{array}{c}0.76 \\
(0.067)\end{array}$ & $\begin{array}{c}0.76 \\
(0.067)\end{array}$ & $\begin{array}{c}0.77 \\
(0.044)\end{array}$ & $\begin{array}{c}0.75 \\
(0.054)\end{array}$ & & \\
\hline Beverage & PC Cola 2L & $\begin{array}{c}0.96 \\
(0.082) \\
\end{array}$ & $\begin{array}{c}0.95 \\
(0.105) \\
\end{array}$ & $\begin{array}{c}1.07 \\
(0.036) \\
\end{array}$ & $\begin{array}{c}1.04 \\
(0.070) \\
\end{array}$ & & \\
\hline Beverage & $\begin{array}{l}\text { Super C Natural } \\
\text { Spring Water 1.5L }\end{array}$ & & & & & $\begin{array}{c}0.68 \\
(0.024)\end{array}$ & $\begin{array}{c}0.68 \\
(0.024)\end{array}$ \\
\hline Beverage & Super C Cola 2L & & & & & $\begin{array}{c}0.99 \\
(0.017) \\
\end{array}$ & $\begin{array}{c}0.93 \\
(0.100) \\
\end{array}$ \\
\hline Beverage & $\begin{array}{l}\text { Super C Mineral Water } \\
1 \mathrm{~L}\end{array}$ & & & & & $\begin{array}{c}0.79 \\
(0.007)\end{array}$ & $\begin{array}{c}0.79 \\
(0.007)\end{array}$ \\
\hline Breakfast/Cereals & PC Corn Flakes 750g & $\begin{array}{c}2.94 \\
(0.179)\end{array}$ & $\begin{array}{c}2.94 \\
(0.179)\end{array}$ & $\begin{array}{c}3.28 \\
(0.249)\end{array}$ & $\begin{array}{c}3.26 \\
(0.269)\end{array}$ & & \\
\hline Breakfast/Cereals & PC Crispy Rice 525g & $\begin{array}{c}2.20 \\
(0.346) \\
\end{array}$ & $\begin{array}{c}2.20 \\
(0.346) \\
\end{array}$ & $\begin{array}{c}2.74 \\
(0.109) \\
\end{array}$ & $\begin{array}{c}2.69 \\
(0.105) \\
\end{array}$ & & \\
\hline Breakfast/Cereals & $\begin{array}{l}\text { Super C Corn Flakes } \\
675 g\end{array}$ & & & & & $\begin{array}{c}2.75 \\
(0.088)\end{array}$ & $\begin{array}{c}2.74 \\
(0.103)\end{array}$ \\
\hline $\begin{array}{l}\text { Condiments, Sauces } \\
\text { and Spread }\end{array}$ & PC Ketchup 1 L & $\begin{array}{c}2.09 \\
(0.149) \\
\end{array}$ & $\begin{array}{c}2.09 \\
(0.149) \\
\end{array}$ & $\begin{array}{c}2.30 \\
(0.197) \\
\end{array}$ & $\begin{array}{c}2.20 \\
(0.219) \\
\end{array}$ & & \\
\hline
\end{tabular}




\begin{tabular}{|c|c|c|c|c|c|c|c|}
\hline $\begin{array}{l}\text { Condiments, Sauces } \\
\text { and Spread }\end{array}$ & $\begin{array}{l}\text { PC Original Whipped } \\
\text { Salad 950ml }\end{array}$ & $\begin{array}{c}2.60 \\
(0.212)\end{array}$ & $\begin{array}{c}2.60 \\
(0.212)\end{array}$ & $\begin{array}{c}3.38 \\
(0.650)\end{array}$ & $\begin{array}{c}3.35 \\
(0.661)\end{array}$ & & \\
\hline Dairy Products & Super C Butter 454g & & & & & $\begin{array}{c}2.95 \\
(0.080)\end{array}$ & $\begin{array}{l}2.95 \\
(.100)\end{array}$ \\
\hline Dairy Products & $\begin{array}{l}\text { Super C Cheddar } \\
\text { Cheese 600g }\end{array}$ & & & & & $\begin{array}{c}5.09 \\
(0.220)\end{array}$ & $\begin{array}{c}5.08 \\
(0.215)\end{array}$ \\
\hline Frozen Food & $\begin{array}{l}\text { Super C Buttermilk } \\
\text { Pancake 310kg }\end{array}$ & & & & & $\begin{array}{c}1.73 \\
(0.098)\end{array}$ & $\begin{array}{c}1.73 \\
(0.098)\end{array}$ \\
\hline Frozen Food & $\begin{array}{l}\text { Super C Pizza Lunch } \\
1.2 \mathrm{~kg}\end{array}$ & & & & & $\begin{array}{c}6.34 \\
(0.230) \\
\end{array}$ & $\begin{array}{c}6.33 \\
(0.234) \\
\end{array}$ \\
\hline Households & PC Fabric Softener 3L & $\begin{array}{c}3.99 \\
(0.000)\end{array}$ & $\begin{array}{c}3.99 \\
(0.000)\end{array}$ & $\begin{array}{c}4.52 \\
(0.118)\end{array}$ & $\begin{array}{c}4.49 \\
(0.171)\end{array}$ & & \\
\hline Households & $\begin{array}{l}\text { PC Laundry Detergent } \\
3.4 \mathrm{~kg}\end{array}$ & $\begin{array}{c}6.82 \\
(0.382)\end{array}$ & $\begin{array}{c}6.82 \\
(0.382)\end{array}$ & $\begin{array}{c}6.99 \\
(0.000)\end{array}$ & $\begin{array}{c}6.85 \\
(0.348)\end{array}$ & & \\
\hline Households & $\begin{array}{l}\text { Super C Dishwashing } \\
\text { 850ml }\end{array}$ & & & & & $\begin{array}{c}1.77 \\
(0.030)\end{array}$ & $\begin{array}{c}1.76 \\
(0.037)\end{array}$ \\
\hline Households & $\begin{array}{l}\text { Super C Fabric } \\
\text { Softener 3.6L }\end{array}$ & & & & & $\begin{array}{c}1.98 \\
(0.010)\end{array}$ & $\begin{array}{c}1.98 \\
(0.010)\end{array}$ \\
\hline Households & $\begin{array}{l}\text { Super C Laundry } \\
\text { Detergent 3.6kg }\end{array}$ & & & & & $\begin{array}{c}5.94 \\
(0.196)\end{array}$ & $\begin{array}{c}5.80 \\
(0.383)\end{array}$ \\
\hline Households & Super C Maize Oil 2L & & & & & $\begin{array}{c}3.98 \\
(0.009)\end{array}$ & $\begin{array}{c}3.97 \\
(0.036)\end{array}$ \\
\hline Juices & $\begin{array}{l}\text { PC Juice Cocktail } \\
\text { 1.89L }\end{array}$ & $\begin{array}{c}2.91 \\
(0.451) \\
\end{array}$ & $\begin{array}{c}2.91 \\
(0.451) \\
\end{array}$ & $\begin{array}{c}3.22 \\
(0.257) \\
\end{array}$ & $\begin{array}{c}2.99 \\
(0.458) \\
\end{array}$ & & \\
\hline Juices & $\begin{array}{l}\text { PC White Grape Juice } \\
1.82 \mathrm{~L}\end{array}$ & $\begin{array}{c}3.99 \\
(0.000) \\
\end{array}$ & $\begin{array}{c}3.99 \\
(0.000) \\
\end{array}$ & $\begin{array}{c}3.96 \\
(0.073) \\
\end{array}$ & $\begin{array}{c}3.82 \\
(0.283) \\
\end{array}$ & & \\
\hline Juices & $\begin{array}{l}\text { Super C Fruit Punch } \\
\text { Drink 2L }\end{array}$ & & & & & $\begin{array}{c}1.54 \\
(.043)\end{array}$ & $\begin{array}{c}1.54 \\
(.043) \\
\end{array}$ \\
\hline Juices & $\begin{array}{l}\text { Super C Orange Juice } \\
1.89 \mathrm{~L}\end{array}$ & & & & & $\begin{array}{c}2.85 \\
(0.087)\end{array}$ & $\begin{array}{c}2.85 \\
(0.087)\end{array}$ \\
\hline $\begin{array}{l}\text { Paper Towel, Tissue } \\
\text { and Pet Supplies }\end{array}$ & $\begin{array}{l}\text { Super C Bathroom } \\
\text { Double Tissue 24un }\end{array}$ & & & & & $\begin{array}{c}9.82 \\
(0.084)\end{array}$ & $\begin{array}{c}9.80 \\
(0.140)\end{array}$ \\
\hline $\begin{array}{l}\text { Paper Towel, Tissue } \\
\text { and Pet Supplies }\end{array}$ & $\begin{array}{l}\text { Super C Facial Tissue } \\
\text { 250un }\end{array}$ & & & & & $\begin{array}{c}1.46 \\
(0.037)\end{array}$ & $\begin{array}{c}1.44 \\
(0.102)\end{array}$ \\
\hline $\begin{array}{l}\text { Soup / Canned } \\
\text { Foods }\end{array}$ & Super C Mais 398ml & & & & & $\begin{array}{c}0.85 \\
(0.032)\end{array}$ & $\begin{array}{c}0.85 \\
(0.032) \\
\end{array}$ \\
\hline $\begin{array}{l}\text { Soup / Canned } \\
\text { Foods }\end{array}$ & $\begin{array}{l}\text { Super C Small Peas } \\
\text { 398ml }\end{array}$ & & & & & $\begin{array}{c}0.95 \\
(0.061) \\
\end{array}$ & $\begin{array}{c}0.95 \\
(0.061) \\
\end{array}$ \\
\hline $\begin{array}{l}\text { Soup / Canned } \\
\text { Foods }\end{array}$ & $\begin{array}{l}\text { Super C Tomatos } \\
796 \mathrm{ml}\end{array}$ & & & & & $\begin{array}{c}0.98 \\
(0.010)\end{array}$ & $\begin{array}{c}0.98 \\
(0.027)\end{array}$ \\
\hline
\end{tabular}




\section{References}

Anderson, E., N. Jaimovich, and D. Simester (2015), "Price Stickiness: Empirical Evidence of the Menu Cost Channel,” Review of Economics and Statistics 97(4), 813-826.

Anderson, E., B. Malin, E. Nakamura, D. Simester, and J. Steinsson (2017), "Informational Rigidities and the Stickiness of Temporary Sales," Journal of Monetary Economics 90, 64-83.

Campbell, J. and B. Eden (2014), "Rigid Prices: Evidence from U.S. Scanner Data,” International Economic Review 55(2), 423-442.

Cavallo, A. (2018), “Scraped Data and Sticky Prices,” Review of Economics and Statistics 100(1), 105-119.

Chahrour, R.A. (2011), "Sales and Price Spikes in Retail Price Data,” Economics Letters 110, 143-146.

Chakraborty, R., P. Dobson, J. Seaton, and M. Waterson (2015), "Pricing in Inflationary Times: the Penny Drops,” Journal of Monetary Economics 76, 71-86.

Coibion, O., Y. Gorodnichenko, and G.H. Hong (2015), "The Cyclicality of Sales, Regular and Effective Prices: Business cycle and Policy Implications,” American Economic Review 105(3), 993-1029.

Dixon, H., J. Seaton, and M. Waterson (2014), "Price Flexibility in British Supermarkets: Moderation and Recession,” Warwick Economic Research Paper No. 1041, Department of Economics, University of Warwick.

Eichenbaum, M., N. Jaimovich, and S. Rebelo (2011), "Reference Prices, Costs and Nominal Rigidities,” American Economic Review 101(1), 234-262.

Fox, K.J, and I.A. Syed (2016), "Price Discounts and the Measurement of Inflation," Journal of Econometrics 191, 398-406.

Gagnon, E. and D. López-Salido (2020), "Small Prices Responses to Large Demand Shocks,” Journal of the European Economic Association 18(2), 792-828.

Glandon, P.J. (2018), "Sales and the (Mis)measurement of Price Level Fluctuations," Journal of Macroeconomics 58, 60-77.

Gorodnichenko, Y. and O. Talavera (2017), "Price Setting in Online Markets: Basic Facts, International Comparisons, and Cross-Border Integration,” American Economic Review 107(1), 249-282.

Gorodnichenko, Y., V. Sheremirov, and O. Talavera (2018), "Price Setting in Online Markets: Does It Click?” Journal of European Economic Association 16(6), 1764 1811.

Guimaraes, B., and K. Sheedy (2011), "Sales and Monetary Policy," American Economic Review 101, 844-876.

Kehoe, P.J. and V. Midrigan (2007), "Sales and the Real Effects of Monetary Policy," Working Paper No. 652, Federal Reserve Bank of Minneapolis.

Kehoe, P. and V. Midrigan (2015), "Prices Are Sticky after all,” Journal of Monetary Economics 75, 35-53.

Klenow, P. and J. Willis (2007), “Sticky Information and Sticky Prices,” Journal of Monetary Economics 54, 79-99.

Klenow, P., and B. Malin (2011), "Microeconomic Evidence on Price Setting.” In

Friedman, B., Woodford, M. (Eds.), Handbook of Monetary Economics, Volume 3A (North Holland: New York, NY), pp. 231-284.

Knotek, E. II (2019), “The Roles of Price Points and Menu Costs in Price Rigidity,” 
Working Paper No. 19-23, Federal Reserve Bank of Cleveland.

Levy, D., M. Bergen, S. Dutta, and R. Venable (1997), “The Magnitude of Menu Costs:

Direct Evidence from Large U.S. Supermarket Chains,” Quarterly Journal of Economics 112(3), 791-825.

Levy, D., D. Lee, H.A. Chen, R. Kauffman, and M. Bergen (2011), "Price Points and

Price Rigidity,” Review of Economics and Statistics 93(4), 1417-1431.

Levy, D. A. Snir, A. Gotler and H. Chen (2020)," Not All Price Endings Are Created

Equal: Price Points and Asymmetric Price Rigidity,” Journal of Monetary Economics 110 (April), 33-49.

Midrigan, V., (2011), “Menu Costs, Multiproduct Firms and Aggregate Fluctuations,” Econometrica 79(4), 1139-1180.

Nakamura, E. (2008), "Pass-Through in Retail and Wholesale,” American Economic

Review: Papers \& Proceedings 98(2), 430-437.

Nakamura, E., and J. Steinsson (2008), "Five Facts about Prices: a Reevaluation of Menu

Cost Models," Quarterly Journal of Economics 123(4), 1415-1464.

Nakamura, E., and J. Steinsson (2011), "Price Setting in Forward-Looking Customer

Markets,” Journal of Monetary Economics 58(3), 220-233.

Nakamura, E., and J. Steinsson (2013), "Price Rigidity: Microeconomic Evidence and Macroeconomic Implications,” Annual Review of Economics 5(1), 133-163.

Nakamura, E., J. Steinsson, P. Sun, and D. Villar (2018), “The Elusive Costs of Inflation:

Price Dispersion during the US Great Inflation,” Quarterly Journal of Economics 133(4), 1933-1980.

Risley, D. (2020), “Does Ending the Price in 7 Really Matter?” Guide to Pricing Your Products (6-Part Series), September 3, 2020, https://www.blogmarketingacademy.com/prices-ending-in-7/, accessed December 28, 2020.

Snir, A., and D. Levy (2021), "If You Think 9-Ending Prices Are Low, Think Again," Journal of the Association for Consumer Research 6(1), 33-47.

Sudo, N., K. Ueda, K. Watanabe, and T. Watanabe (2018), "Working Less and Bargain Hunting More: Macroimplications of Sales during Japan’s Lost Decades,” Journal of Money, Credit and Banking 50(2-3), 449-478.

Syed, I. (2015), "Sale Spotter: An Algorithm to Identify Sale Prices in Point-of-Sale Data,” UNSW Business School Research Paper No. 2015 ECON 13. 